\title{
Zofia Romanowiczowa. Zarys twórczości i recepcji ${ }^{1}$
}

\section{Zofia Romanowiczowa. The outline of output and critical reception}

\section{Streszczenie:}

W artykule koncentruję się na przedstawieniu zarysu twórczości prozatorskiej Zofii Romanowiczowej oraz jej recepcji. Każdej z jedenastu opublikowanych powieści pisarki poświęcam fragment artykułu, uwypuklając ich stylistyczne podobieństwa oraz podkreślając charakterystyczną dla całej twórczości Romanowiczowej tematykę i problematykę. Część poświęcona recepcji ma z kolei stać się punktem wyjścia do rozważań o kanonie literatury polskiej XX wieku.

Słowa kluczowe: kanon, kobieta, pamięć, historia, eksperyment, recepcja twórczości, literatura emigracyjna

\begin{abstract}
:
The author of the article focuses on an overall picture of Zofia Romanowiczowa's prose works and their critical reception. For each of eleven published novels of the author there was devoted a distinct part of the text, emphasizing at the same time the similarities in style and subjects so charac-
\end{abstract}

\footnotetext{
${ }^{1}$ Artykuł powstał na podstawie mojej książki „Eksperyment w prozie Zofii Romanowiczowej" (Wydawnictwo Uniwersytetu Łódzkiego, Łódź 2015).
} 
Natalia Królikowska - Zofia Romanowiczowa. Zarys...

teristic in all of writer's work. In turn the part devoted to the critical reception is supposed to be the starting point for a reflection about the canon of twentieth century Polish literature.

Keywords: canon, history, memory, woman, gender, experimental literature, emigration literature

\section{Wprowadzenie}

Pomimo że ogromnie zasłużona dla kultury polskiej i przed laty ceniona zarówno w literackich kręgach emigracji, jak i rodzimej krytyki, Zofia Romanowiczowa jest dziś pisarką mało znaną. Poza monograficzną rozprawą Anny Jamrozek-Sowy, zatytułowaną Życie powtórzone. O pisarstwie Zofii Romanowiczowej, oraz wydanym w formie książkowej zbiorem szkiców Włodzimierza Wójcika $W$ Polsce $i$ na Obczyźnie. O pisarstwie Zofii Romanowiczowej, większość - wszak nie nadmiernie licznych - opracowań dotyczących twórczości tej autorki zawarta jest w czasopismach, publikacjach pokonferencyjnych czy słownikach. W artykułach podkreśla się zagadnienia historyczne, psychologiczne, egzystencjalne i etyczne, jednak formułowane wnioski mają zwykle charakter fragmentaryczny, odnoszą się do jednego utworu bądź wybranego zagadnienia. Stąd - podjęta w niniejszym artykule - próba wyjaśnienia nieobecności Zofii Romanowiczowej w polskim literaturoznawstwie.

\section{Zofia Romanowiczowa - dzieciństwo, wojna i debiut}

Zofia Romanowiczowa przyszła na świat w Radomiu w 1922 roku w inteligenckiej, niezbyt zamożnej rodzinie. Jej ojciec, Zygmunt Górski, były legionista i urzędnik państwowy, dbał o patriotyczne wychowanie swoich dzieci. Jego żona, matka Zofii, Marianna ze Stolińskich, zajmowała się domem. Po wybuchu II wojny światowej część rodziny przeniosła się do wiejskiego majątku Stolińskich w Goździ- 
kowie. Zofia wraz z ojcem pozostała w Radomiu, gdzie oboje zostali aresztowani w 1941 roku za działalność konspiracyjną. Po odesłaniu z wyrokiem śmierci z prowizorycznego aresztu gestapo w SkarżyskuKamiennej, urządzonego w Szkole Podstawowej im. Józefa Piłsudskiego, przez blisko rok trzymana była w więzieniu kieleckim, później - w pińczowskim, kolejne dwa lata spędziła w kobiecym obozie koncentracyjnym w Ravensbrück, a ostatnie miesiące II wojny światowej - w komando fabrycznym w Neu Rohlau koło Karlsbadu. Z niemieckiej niewoli wyciągnęła ją pani Rychlewiczowa z Polskiego Czerwonego Krzyża. W 1946 roku zdała polską maturę w szkole 2 Korpusu Polskiego w San Giorgio we Włoszech i (za namową swojego mentora, Melchiora Wańkowicza, i przy wsparciu księdza Tadeusza Kirschke) wyjechała do Francji, gdzie podjęła studia filologiczne na paryskiej Sorbonie, specjalizując się w prowansalistyce². W 1948 roku w Paryżu wyszła za mąż za polskiego emigranta, wydawcę i księgarza - Kazimierza Romanowicza3 . „Potem według własnego jej ujęcia - małżeń-

\footnotetext{
${ }^{2} 0$ wyborze kierunku studiów i o naukowych zasługach Romanowiczowej dla prowansalistyki mówił m.in. Tymon Terlecki we wstępie do jednego ze spotkań autorskich z pisarką: „Nie można opanować zadziwienia wobec tego wyboru. Prowansalistyka zajmuje się literaturą i kulturą średniowiecznej Prowansji, kraju na południowym pograniczu francuskim na płodnym przeciągu Włoch i Hiszpanii, leżącego dziś bardziej w strefie poetyckiego urojenia niż pod określoną szerokością geograficzną [...]. Chce mi się myśleć, że zanurzenie się po głowę w odległym świecie było oczyszczającą kąpielą, wypłukującą wszystkie brudy i potworności, to na co napatrzyły się dziewczęce oczy, to czym nasiąkł mózg ledwie odciągnięty od zabawy. Było to studium jak najbardziej serio. Dowodzi tego tom Biblioteki Narodowej noszący tytuł Brewiarz miłości, zawierający uczony wstęp, świetne objaśnienia, kilkadziesiąt własnych przekładów poezji staroprowansalskiej. Są to najwierniejsze przekłady trubadurów jakie istnieją w polszczyźnie, godne stanąć obok przekładów uczonego i poety Edwarda Porębowicza, tłumacza Boskiej Komedii" (T. Terlecki, Zofia Romanowiczowa i „le nouveau roman”, „Wiadomości” 1975, nr 22). Pozytywną recenzję Brewiarza miłości napisał Józef Wittlin, nazywając w niej autorkę „najwybitniejszym, a może jedynym po śmierci prof. Stanisława Strońskiego, przedstawicielem prowansalistyki polskiej" (Idem, Brewiarz miłości [w:] Idem, Eseje rozproszone, oprac. P. Kądziela, Warszawa 1995).

${ }^{3}$ Kazimierz Romanowicz urodził się 9 listopada 1916 roku w Lemieszówce koło Kamieńca Podolskiego. Przed wybuchem II wojny światowej pracował w dziale francuskim prestiżowej księgarni Gebethnera i Wolffa, skąd w 1937 roku został oddele-
} 
Natalia Królikowska - Zofia Romanowiczowa. Zarys...

stwo, macierzyństwo, same prywatności"45. Tymczasem lata 19562001 to długi i owocny okres jej twórczej działalności, w ciągu którego wydała jedenaście powieści i jeden zbiór opowiadań.

gowany na staż zawodowy do Księgarni Polskiej w Paryżu. Tam, wraz z kierownikiem placówki, Tadeuszem Pajorem, otworzył w 1939 roku filię składu przy ulicy Taitbout 23. Po rozpoczęciu wojny zgłosił się jako ochotnik do powstającego we Francji Wojska Polskiego. W 1942 roku został skierowany do 2 Korpusu Polskiego na Bliski Wschód. W stopniu podporucznika z Korpusem przeszedł kampanię włoską. Po wojnie został mianowany kierownikiem księgarni „Libella”, utworzonej jako placówka kontynuująca działalność wydawniczą Oddziału Kultury i Prasy 2 Korpusu, z siedzibą na paryskiej Wyspie św. Ludwika. Od 1947 r. aż do zamknięcia księgarni (31 grudnia 1993 r.) zajmował się działalnością księgarską i wydawniczą. W 1959 roku w przylegającym do księgarni pomieszczeniu założył Galerię Lambert, w której prezentowano najnowsze dokonania plastyczne o polskim i światowym rodowodzie. Zmarł w wieku 93 lat w szpitalu w Orleanie. 28 września 2010 r. został pośmiertnie odznaczony Krzyżem Komandorskim z Gwiazdą Orderu Zasługi Rzeczypospolitej Polskiej. Więcej na temat Kazimierza Romanowicza i prowadzonej przez niego działalności wydawniczej i wystawienniczej: A. Kłossowski, Instytucja spełnionej nadziei. Paryska Libella i Galeria Lambert Zofii i Kazimierza Romanowiczów, Warszawa 1994/1995; Idem, Książka polska na obczyźnie: XX wiek, wybór i wstęp M. A. Supruniuk i J. Tondel, Toruń 2003; Idem, Ksieggarnie polskie we Francji w XX wieku, [w:] Idem, Kultura skupisk polonijnych, Warszawa 1984; Idem, Na obczyźnie. Ludzie polskiej książki, Wrocław 1984; Idem, Paryska Libella. Czterdzieści lat w służbie kultury polskiej, [w:] O język i kulturę polskq $w$ środowiskach polonijnych. Materiały z II Konferencji Okragłego Stołu. Łańcut, 26-28 lipca 1986 r., pod red. R. Kantora i J. Rokickiego, Warszawa 1990; Idem, Polski ruch wydawniczy we Francji po II wojnie światowej (1945-1989), „Editor”, t. 3 (1990); Idem 40 lat paryskiej „Libelli”, „Przegląd Księgarski i Wydawniczy”, Warszawa 1986, nr 6; A. Janas, Ambasady polskiej książki, „Dziennik Bałtycki” 1986, nr 195; „Jeździłem po Nordzie z walizkami ksiq̨żek...”. Z Kazimierzem Romanowiczem rozmawia Barbara Kazimierczyk, „Nowe Książki” 1995, nr 2; K. Jeleński, Polski sezon plastyczny w Paryżu, „Kultura” [Paryż] 1960, nr 7-8; Idem, Polskie wystawy w Paryżu, „Kultura” [Paryż] 1960, nr 9; K. Sobolewski, Polska na Wyspie św. Ludwika, „Kurier Polski" 1994, nr 273; M. A. Supruniuk, Nowe rozdanie. Polskie artystki w Galerii Lambert Zofii i Kazimierza Romanowiczów, „Archiwum Emigracji” 2012, z. 1-2; K. Wierzyński, Galeria Romanowicza, „Wiadomości” 1960, nr 33; A. Olszewska, Paryska „Libella” Romanowiczów, „Wydawca” 1998, nr 1.

${ }^{4}$ M. Z., Doroczne nagrody „Kultury” za rok 1985 [online], http://www.kultura paryska.com/uploadfiles/file/nagrody/nlh_1985-.pdf [dostęp 09.03.2015].

${ }_{5}^{5}$ Pierwsze paryskie lata przyszłej pisarki Jan Bielatowicz określa „drugim wielkim doświadczeniem życia Zofii Górskiej, wkrótce Romanowiczowej” i uzasadnia swój sąd: „stało się tam naraz bardzo wiele: po raz pierwszy życie samodzielne, studia, Paryż, nowy język, druga ojczyzna, małżeństwo, macierzyństwo. Miód się sączył do duszy razem z piołunem, i już za progiem stała niecierpliwa, narastająca, gorąca i burząca się twórczość” (Idem, Zosia i Zofia, „Wiadomości” 1964, nr 23). 
Wydaje się, że nieprzypadkowo rok debiutu pisarki ${ }^{6}$ to także data rozpoczynająca moment $\mathrm{w}$ historii literatury, dla niej samej przełomowy ${ }^{7}$. Pierwsze powojenne lata były trudne, zarówno dla literatury krajowej, jak i emigracyjnej. W Polsce Ludowej obowiązujący powszechnie ton wyznaczało czasopismo „Kuźnica”. Młodzi, debiutujący po wojnie pisarze, marzący o przeżyciu wielkiej przygody dla sprawy, śmiało flirtowali $\mathrm{z}$ realizmem socjalistycznym, traktując komunizm „jak nową objawioną religię; podobnie teoria marksizmu wydawała się «pryszczatym» jednocześnie dekalogiem i współczesną powieścią"8. Jak zauważa Jerzy Poradecki:

O całości i jednolitości okresu 1945-1955 decydowała więc nie postawa takich pisarzy jak Kott, Andrzejewski, Jastrun, Ważyk i inni, których przygoda z realizmem socjalistycznym była nieustannym ciągiem wątpliwości i nawróceń, ale jednolita i konsekwentna droga do niego pisarzy debiutujących już po wojnie, szczególnie grupy „pryszczatych”.

Z kolei ruch wydawniczy pierwszej połowy lat 50. XX w. na obczyźnie, wolny od socjalistycznej doktryny, borykał się z problemami instytucjonalnymi i organizacyjnymi. Wydawano niewiele pozycji, a kryteria ich wyboru wydają się z dzisiejszej perspektywy dość chaotyczne i niejasne, z pewnością nie są to jednak kryteria stricte literackie czy estetyczne $^{10}$. Moment debiutu Romanowiczowej, a co pewniejsze -

\footnotetext{
${ }^{6}$ Rok 1956 to rok podwójnego debiutu - nie tylko Zofii Romanowiczowej jako pisarki, ale również wydawnictwa „Libella”, założonego przez małżeństwo. Baśka i Barbara otwiera listę tytułów, wydawanych przez „Libellę” nieprzerwanie do 1990 roku. Por. R. Gorczyńska, Z ziemi włoskiej do Francji. Zofia i Kazimierz Romanowiczowie [w:] tejże, Portrety paryskie, Kraków 1999.

${ }^{7}$ O latach 1956-1976 Ryszard Nycz pisze jako o przełomowym okresie dla literatury współczesnej, nazywając go „fazą krytycznego przemyślenia własnego charakteru, społecznego i kulturalnego położenia, artystycznego i intelektualnego dziedzictwa" (Idem, Sylwy współczesne, Kraków 1996, s. 6).

${ }^{8}$ A. Lisiecka, Pokolenie „pryszczatych”, Warszawa 1964, s. 14.

${ }^{9}$ J. Poradecki, Pisarstwo Wilhelma Macha, Łódź 1984, s. 8.

${ }^{10}$ We wstępie do artykułu, zamieszczonego w londyńskim „Życiu” w 1956 roku, recenzent Baśki i Barbary pisał: „Książek polskich wychodzi poza krajem sporo, w ostatnim pięcioleciu przeciętnie po 50 tomów rocznie. W tej pięćdziesiątce mieszczą się prace naukowe, pamiętniki, wznowienia, a nie brak też rzeczy całkiem bła-
} 
Natalia Królikowska - Zofia Romanowiczowa. Zarys...

lata 60. (na początku których ukazały się dwie najlepsze powieści pisarki - Przejście przez Morze Czerwone, 1960 oraz Słońce dziesięciu linii, 1963), narzuciły pisaniu Romanowiczowej obowiązujący w pewnym stopniu do dziś, wywiedziony z konceptualistycznych poetyk i awangardowych eksperymentów, model tworzenia literatury.

Przełom lat 50. i 60. XX wieku to czas poszukiwań nowego paradygmatu literackiego. Dowodem na panującą wówczas atmosferę eksperymentowania może być chociażby prześledzenie kontekstów literackich, w których pojawiały się recenzje i artykuły krytyczne pierwszych utworów Zofii Romanowiczowej. Francuski krytyk, Marcel Brion, publikujący m.in. w opiniotwórczym „Le Monde” czy „Les Nouvelles Littéraires", recenzował Przejście przez Morze Czerwone wraz z innymi wybitnymi polskimi dziełami literackimi XX wieku Traktatem o manekinach Brunona Schulza oraz Bramami Raju Jerzego Andrzejewskiego ${ }^{11}$. Zadziwiające z dzisiejszej perspektywy wydaje się to, że nawet w konserwatywnym „Żołnierzu Wolności” recenzja Baśki i Barbary pojawiła się obok recenzji Wykładu profesora Mmaa Stefana Themersona ${ }^{12}$. Józef Wittlin, przedstawiając w londyńskich „Wiadomościach" w roku 1959 (a więc jeszcze przed wydaniem przez Romanowiczową jej najwybitniejszych powieści, co dobitnie świadczy o wysokiej randze opowiadań ukazujących się na łamach czasopism), najzdolniejszych pisarzy młodego pokolenia, wymieniał pisarkę obok Gustawa Herlinga-Grudzińskiego i Tadeusza Nowakowskiego ${ }^{13}$. Inspiracji i patronów twórczości autorki Skrytek krytyka upatrywała

hych, a nawet i płodów maniackich. Dobry tom prozy trafia się nieczęsto. O wartościową powieść szczególnie trudno. W okresie lat 1947-1956 pojawiło się na emigracji niewiele więcej dobrych literacko powieści niż palców u obu rąk. Całą godną uwagi twórczość prozaiczną w tych latach można w przybliżeniu określić na ćwierć setki tomów. A więc przeciętnie emigracja wydaje 2-3 tomy dobrej prozy rocznie. Najpiękniejszym wydarzeniem roku bieżącego w prozie emigracyjnej jest Baśka i Barbara Zofii Romanowiczowej” (J. B., Baśka i Barbara, „Życie” 1956, nr 37).

${ }^{11}$ Por. M. Brion, Fantastique, bizarre..., „Les Nouvelles Littéraires” 1962, nr 1798; Idem, Trois romans polonais, „Le Monde” 1961, nr 5141.

${ }^{12}$ Por. M. Bielicki, Dwie ksiq̨żki pisane „stamtąd”, „Żołnierz Wolności” 1958, nr 73.

${ }^{13}$ Por. J. Wittlin, Młoda proza emigracyjna, „Wiadomości”1959, nr 34. 
zarówno wśród fundatorów egzystencjalizmu, Jeana Paula Sartre'a i Alberta Camusa i twórców nowej powieści - Nathalie Saurraute i Robbe-Grilleta ${ }^{14}$, jak i pisarzy polskich - Marii Kuncewiczowej15, Tadeusza Borowskiego czy Tadeusza Różewicza ${ }^{16}$, a nawet (sic!) Stefana Żeromskiego ${ }^{17}$. Józef Wittlin porównywał krótkie formy prozatorskie Romanowiczowej do poczytnych opowiadań skandalizującej Katherine Mansfield - z korzyścią dla pisarki polskiej: „Opowiadania Romanowiczowej, np. takie jak Tanzabend w Grasecku lub Moje ty słońce..., należą do najświetniejszych osiągnięć współczesnej nowelistyki kobiecej. Nie tylko polskiej. Wobec tematyki Romanowiczowej nawet biedna gruźliczka Katherine Mansfield, mistrzyni rodzaju literackiego, która uprawia Romanowiczowa, musi usunąć się w cień laurów i palm francuskiej Riwiery"18.

Niejednolite stylowo, miejscami nierówne pisarstwo Romanowiczowej jest wyrazistym dowodem przejściowości tej literatury, jej mniej lub bardziej udanych poszukiwań i eksperymentów formalnych ${ }^{19}$. Odbija się w nim wiele nurtów materii literackiej ostatniego stulecia, takich jak chociażby spersonalizowane i subiektywne formy narracji z ducha powieści egzystencjalistycznych czy sposoby przedstawiania rzeczywistości inspirowane nouveau roman. W żartobliwym

\footnotetext{
${ }^{14}$ Por. B. Mamoń, Strach przed drugim brzegiem, „Tygodnik Powszechny” 1961, nr 31.

${ }^{15}$ Por. J. Detka, Zofia Romanowiczowa [w:] Pisarze regionu świętokrzyskiego, J. Pacławski (red.), Kielce 1997, s. 185-224.

${ }^{16}$ D. Mazurek, Kobieta i wojna. O twórczości Zofii Romanowiczowej [w:] Kobieta w literaturze i kulturze, D. Mazurek (red.), Lublin 2004.

${ }^{17}$ M. Danilewicz-Zielińska, Szkice o literaturze emigracyjnej, Wrocław 1992, s. 190 192.

${ }^{18}$ J. Wittlin, Młoda proza emigracyjna, „Wiadomości” 1959, nr 34.

${ }^{19}$ Niedoskonałość literatury i ułomność sztuki to również wyraz koncepcji światopoglądowej w humanistyce powojennej, którą trafnie wyraził w Kupcu łódzkim Adolf Rudnicki: „Wszelkie sądy, widzenia płynące tylko z mózgu, mają w sobie natrętną nieprawdę, brak im błędu, bez którego nic nie żyje naprawdę. Błąd zbliża dzieło, jak wada człowieka" (Idem, Kupiec łódzki, Warszawa 1969, s. 234). Sednem tej koncepcji jest silnie upodmiotowiona prezentacja, skoncentrowana na tych motywach, które traumatyzują jednostkę.
} 
Natalia Królikowska - Zofia Romanowiczowa. Zarys...

tonie o pisarskich poszukiwaniach Romanowiczowej pisała Stanisława Jazówna, tłumacząc nietrafione eksperymenty:

\begin{abstract}
Nie jest żadną winą autorów, że własnej epoce spłacają długi i biorą z niej pełnymi rękami, obok rzeczy trwałych i jej dziwactwa. Dziwactwem kilku «nowych fal» był w powieści komentarz odautorski, nieraz długi jak legendarny wąż morski, który tylu książkom zjadł nie tylko czytelność i dobrą budowę, ale także cały smak literatury: artyzm. Romanowiczowa, choć kuszona przez węża nieco wyżej się wygrzewającego w zdaniu, strzegła się zawsze tego, by opowiadanie czy powieść nie zamieniło się $\mathrm{w}$ jeden pokraczny i zawiły margines analityczny [...]. Zbytnie jednak czasem pójście za „strumieniem świadomości” rozluźniało w poprzednich książkach przelewającą się i nie mogącą okrzepnąć semantycznie magmę słowną ${ }^{20}$.
\end{abstract}

\title{
2. Miejsce twórczości Zofii Romanowiczowej w polskim literaturoznawstwie
}

Z pewnością Zofia Romanowiczowa nie jest pisarką doskonałą, perfekcyjnie i bezbłędnie operującą tworzywem, z którym przyszło jej przez ponad pół wieku pracować. Mimo to, brak jej twórczości w polskim literaturoznawstwie to wiele znaczące „puste miejsce”. We wstępie do artykułu poświęconego jednej z najlepszych powieści Romanowiczowej Iwona Gralewicz-Wolny stwierdza dobitnie:

Czytając Skrytki Zofii Romanowiczowej, nie sposób uciec od pytania, ile jest jeszcze w polskiej literaturze utworów tak ciekawych i tak całkowicie zapomnianych? Skrytki z całą pewnością zasłużyły na coś więcej niż tylko jedno emigracyjne wydanie, którego próżno szukać w bibliotekach ${ }^{21}$.

Powody tej niezwykłej absencji są różnorakie - poczynając od tych związanych z wydarzeniami historycznymi i przewrotami politycznymi, a na najbardziej osobistych, psychologicznych kończąc. Delikatnie i subtelnie odbiegające od głównego nurtu literatury, nieśmiało ekspe-

\footnotetext{
${ }^{20}$ S. Jazówna, $O$ „Łagodnym oku błękitu” Zofii Romanowiczowej, „Kronika” 1968, nr 49-50.

${ }^{21}$ I. Gralewicz-Wolny, Skrytki w sercach. O jednej powieści Zofii Romanowiczowej, [w:] Rodzina w czasach przełomów. Literackie diagnozy od XIX do XXI wieku, K. Kralkowska-Gątkowska (red.), Katowice 2011, s. 218.
} 
rymentujące z formami narracyjnymi, sposobami przedstawiania czy tematami i motywami literackimi pisarstwo Romanowiczowej pomijano w opracowaniach syntetyzujących literaturę polską XX wieku. Emigracyjna proza pisarki nie zasymilowała się do dziś z polską historią literatury, choć być może właśnie teraz - w horyzoncie teraźniejszości historycznoliterackiej - chętniej wchodzi ona w dialog ze współczesnymi metodologiami analitycznymi. Tym bardziej dziwi brak Romanowiczowej w refleksji badaczek feministycznych.

Genologia feministyczna jest w swojej istocie mocno Foucaultowska, a więc nielinearna, niechronologiczna, nie dążąca do systematyczności, a w zamian - oparta w głównej mierze na osobistych fascynacjach i poszukiwaniach badaczek. Nie raz naukowe interpretacje ze szkoły studiów kobiecych wydobyły z niepamięci nazwiska, teksty, zjawiska estetyczne oraz procesy społeczne warunkujące twórczość kobiet-autorek. Do najistotniejszych monograficznych prac historycznoliterackich polskich women studies należą dziś m.in. prace Krystyny Kłosińskiej o Gabrieli Zapolskiej22, Izabeli Filipiak o Marii Komornickiej $^{23}$ czy Agaty Araszkiewicz o Zuzannie Ginczance ${ }^{24}$. Wszystkie one oparte są na empatycznym współodczuwaniu przez badaczki omawianych tekstów. Tak też interpretuje piśmiennictwo kobiet o innych kobietach Inga Iwasiów w słynnym tekście Gender dla średnio zaawansowanych:

Teksty Szczuki, Araszkiewicz, przede wszystkim zaś Kłosińskiej [...] wychodząc od historii literatury, zmierzają do momentu lektury rozumianej jako podmiotowy akt twórczy. Czerpiący inspirację z faktu istnienia babek, które jednakże nie są już rozdziałami w sprawiedliwie skomponowanej przeszłości. Są partnerkami wysiłku kreacyjnego, zwróconego ku teraźniejszości25.

\footnotetext{
${ }^{22}$ K. Kłosińska, Ciało, pożądanie, ubranie: o wczesnych powieściach Gabrieli Zapolskiej, Kraków 1999.

${ }^{23}$ I. Filipiak, Obszary odmienności: rzecz o Marii Komornickiej, Gdańsk 2006.

${ }^{24}$ A. Araszkiewicz, Wypowiadam wam moje życie: melancholia Zuzanny Ginczanki, Warszawa 2001.

${ }^{25}$ I. Iwasiów, Gender dla średnio zaawansowanych. Wykłady szczecińskie, Warszawa 2004, s. 35.
} 
Konstruktywistyczny charakter women studies jest charakterystyczny nie tylko dla badań feministycznych, ale dla wszelkich teorii wywodzącym się $\mathrm{z}$ ducha nowego historyzmu i dekonstrukcji26. Impuls teoretyczny ich założeń przeniósł punkt ciężkości badań z opisu Systemu na systemy lokalne oraz z Historii na historie, odsłaniając interpretacyjny charakter dziejów. Idea tekstualności otworzyła drogę nowemu rozumieniu historyczności, włączając w obszar historii literatury także te utwory, które były do tej pory pomijane bądź marginalizowane. Włodzimierz Bolecki w pracy Czym stała się dziś historia literatury ${ }^{27}$ zwraca uwagę, że skoro nie ma jednego rozumienia historyczności, to nie może być też mowy o jednej, obiektywnej prawdzie na temat historii piśmiennictwa. Profesor przyznaje, że obowiązujący przez lata normatywizm w syntezie historycznoliterackiej prowadził do selektywności. Tymczasem, jak zauważa Maria Janion, „znaczenia zastygłe w dogmatach albo porzucone i opuszczone zaciemniają obraz rzeczywistości, obezwładniają i paraliżują, uniemożliwiając tym samym nowe rozpoznania i przekształcenia"28. Dlatego czytanie autorek mało znanych, nawet tych drugo- i trzeciorzędnych daje pełniejszy obraz każdej, w tym polskiej, historii literatury. Przy okazji, poszerzając wiedzę o sposobach pisania, odpowiada na pytanie o to, w jaki sposób kobiece pisanie odnosi się do norm pisania - czy je znosi, czy konserwuje oraz o to, jak pod wpływem literatury kobiecej zmienia się kanon i norma oraz jak należy badać te zjawiska, mając do dyspozycji współczesne metodologie teoretycznoliterackie. Powstaje zatem pytanie - dlaczego feminizujące badaczki nie znają Zofii Romanowiczowej? Dlaczego jej twórczości nie ma nawet w stworzonym przez nie alternatywnym, „kobiecym kanonie”? Wszak kanon to zbiór dzieł, o których członkowie określonej grupy społecznej powinni coś wiedzieć. Wiedza ta, według Andrzeja Szpocińskiego, stanowi upostacio-

${ }^{26}$ T. Walas, Czy jest możliwa inna historia literatury?, Kraków 2003.

${ }^{27}$ W. Bolecki, Czym stała się dziś historia literatury, [w:] Wiedza o literaturze i edukacja Księga referatów Zjazdu Polonistów, T. Michałowska, Z. Goliński, Z. Jarosiński (red.), Warszawa 1996, s. 44.

${ }^{28}$ M. Janion, Czytać jeszcze raz, [w:] eadem, Odnawianie znaczeń, Kraków 1980, s 24. 
wanie idei, wartości i wzorów zachowań oraz symbolizuje samą grupę ${ }^{29}$. Jak podkreśla inny badacz - Jerzy Szacki: „kanon kultury jest koniecznie czyjś: pytanie o kanon jest ostatecznie pytaniem o wspólnotę, która go wytworzyła i uważa za własny"30. Kanon to także - jak definiuje go Leszek Szaruga - przestrzeń porozumienia:

Bez niego nie da się pomyśleć wspólnego dyskursu, on bowiem ustala zrozumiały dla wszystkich jego uczestników idiom, bez którego wszelki dialog musi się przekształcić w wygłaszane obok siebie i nie pozostające ze sobą w związku monologi ${ }^{31}$.

Pytanie o kanon ewokuje pytanie o tożsamość oraz o relacje między jednym a drugim. W tym kontekście trzeba zastanowić się, czy utwory Romanowiczowej należy próbować włączyć do kanonu literatury narodowej, posługując się przy tym kryterium języka ${ }^{32}$, w jakim ta literatura była tworzona, czy starać się pokazać ją w kontekście geneologii kobiecej, posługując się alternatywną dla języka kategorią płci (autora, tekstu, bohaterów). Syntezą tych dwóch propozycji wydaje się być stanowisko Germana Ritza, stwierdzające, iż polskie literaturoznawstwo rozpoczęło rekonstrukcję kobiecej geneologii w latach 90. XX wieku nie tylko po to, aby ukazać zatarte ślady obecności kobiet w kulturze, ale przede wszystkim po to, aby „uzupełnić luki w wiedzy

\footnotetext{
${ }^{29}$ A. Szpociński, Kanon kulturowy, „Kultura i Społeczeństwo” 1991, nr 2.

${ }^{30}$ J. Szacki, O kanonie kultury europejskiej uwagi sceptyczne, „Znak” 1994, nr 7.

${ }^{31}$ L. Szaruga, Kanon jako przestrzeń porozumienia, [w:] Kanon i obrzeża, I. Iwasiów, T. Czerska (red.), Kraków, 2005, s. 125.

${ }^{32} \mathrm{O}$ problemach $\mathrm{w}$ posługiwaniu się jednym tylko narodowym kanonem pisze, posługując się obrazowymi przykładami, Leszek Szaruga: „Nie można sensownie czytać współczesnej polskiej powieści, jaką jest Odyseja, Odyseja... Mariana Grześczaka, bez znajomości Odysei Homera. Nie można zrozumieć wierszy Tadeusza Różewicza bez wiedzy o ich uwikłaniu w filozoficzne i poetyckie pisarstwo niemieckie. Nie da się ze zrozumieniem przeczytać Wzlotu Jarosława Iwaszkiewicza bez znajomości Upadku Alberta Camusa. Niemożliwa wreszcie jest interpretacja prozy Gustawa HerlingaGrudzińskiego bez odniesień do pisarstwa Dostojewskiego czy Kafki, tak samo, jak w bełkot musi się przemienić interpretacja Traktatu moralnego Czesława Miłosza bez znajomości Jądra ciemności Conrada. To, oczywiście, jedynie wybrane przykłady, które kwestionują sensowność wyodrębniania «kanonu kultury narodowej» ograniczonego do dzieł tej właśnie kultury" (Ibidem, s. 128-129).
} 
historycznej i stworzyć kanon kultury obejmujący, już nie tylko jedną, ale dwie płcie" 33 .

Problem z umiejscowieniem pisarstwa Zofii Romanowiczowej w rodzimej historii literatury polega również na tym, że jej twórczość nie należy współcześnie, ani nigdy nie należała, do literatury popularnej w znaczeniu gatunkowym, co mogłoby być łatwą diagnozą przyczyn marginalizowania przez historyków i historyczki literatury. Autorka Skrytek wybrała powieść jako swój sztandarowy gatunek literacki, jednak jej twórczość daleka jest od XIX-wiecznej powieści kobiecej - skoncentrowanej głównie na opisie trosk dnia codziennego i przeżyć miłosnych bohaterek ${ }^{34}$. Perspektywa wykreowanych przez Romanowiczową bohaterek nie jest perspektywą z horyzontu XIXwiecznej bawialni. Wręcz przeciwnie - nieraz jest to perspektywa więźnia czy wygnańca, a więc figur do niedawna niedostępnych doświadczeniu kobiecemu, dalekiemu od spraw i zajęć publicznych czy politycznych. Bohaterkom Romanowiczowej dostępne są wszystkie rodzaje doznań, przez co ich horyzont myślowy zdaje się sięgać dalej, a może i głębiej niż męski logos. Józef Wittlin w szkicu Pochwała kobiety piszq̨cej rozważa:

Nie wiem, jaki to mędrzec przeciwstawił umysłowość męską - kobiecej, oczywiście na niekorzyść kobiecej. Ale fakt faktem, że przywykliśmy w twórczości kobiet upatrywać cechy rzekomo dla nich typowe, np. przewagę uczucia nad intelektem lub nerwów nad wyobraźnią. Może okrutna śmierć aleksandryjskiej Hypatii, słynnej filozofki neoplatońskiej i matematyczki na przełomie IV i V w. po Chr., odstraszyła średniowieczne niewiasty od zajmowania się filozofią [...]. Ale z tych odległych czasów i obcych stron przenieśmy się na bliższy nam teren polskiej emigracji, na progu siódmego dziesięciolecia XX w. Ujrzymy tam wcale pokaźną gromadkę dam piszących wierszem i prozą. I nie-

${ }^{33}$ G. Ritz, Nić w labiryncie pożądania. Gender i płeć w literaturze polskiej od romantyzmu do postmodernizmu, Warszawa 2002, s. 10.

${ }^{34}$ Badania z dziedziny socjologii literatury pokazują, że wraz z pojawieniem się publiczności kobiecej na przełomie XVIII i XIX wieku wzrosło zapotrzebowanie na fabuły romansowe. Józef Bachórz zwraca uwagę, że zwrot $w$ stronę romansu odnotowuje się od końca XVIII wieku nie tylko w powieściopisarstwie polskim, ale że jest to zjawisko charakterystyczne dla literatur europejskich w ogóle. Por. J. Bachórz, Romans w powieści, [w:] Tekst i fabuła, Cz. Niedzielski, J. Sławiński (red.), Wrocław 1979. 
kiedy rozsądniej i przenikliwiej niż ich męscy koledzy. Co w twórczości białogłowskiej od razu rzuca się w oczy, to - równowaga ducha, umiar, przytomność, solidna obserwacja środowiska, czasem wielka wiedza, no i rozległość widnokręgów ${ }^{35}$.

Faktycznie, Romanowiczowa dysponowała panoramiczną optyką postrzegania świata. Na jej biografię składają się: rozłąka z matką i rodzeństwem, działalność podziemna, udział w tajnych kompletach, aresztowanie, przesłuchania, więzienia, a w końcu - oswobodzenie i dożywotnia emigracja. Te wszystkie doświadczenia znajdują odbicie w powieściach i opowiadaniach Romanowiczowej. Wielogłos wojennej tragedii tworzy heterotopiczną, złożoną i niezwykle oryginalną, w kontekście dziejów polskiej literatury XX-wiecznej, przestrzeń tekstów prozatorskich. Docenił to krytyk emigracyjny Tadeusz Nowakowski:

Jak to dobrze, że autorka Prób i zamiarów stroni od literackości, sentymentalizmu, tanich psychologizmów, filozofującego komentarza, liryzmów i innych grzechów tzw. „literatury kobiecej”. Wczytując się w ten log podróży w głąb okupacyjnej nocy, spostrzegamy, że ciężar przeżycia nie łamie słownego przęsła, nie zwęża myślowego horyzontu, nie zakłóca jasności widzenia. Ortega y Gasset pisał, że „jedynie myśli rozbitków okrętowych wolne są od fałszu”. W rzeczy samej ocaleni z pożogi wynoszą nieraz spod gruzów zdobycz niepospolitą; iście rentgenowskie spojrzenie na rzeczywistość, zmysł konfrontacji przeszłości z teraźniejszością, swoisty aparat do wykrywania kłamstwa, błogosławioną alergię na punkcie „wielkich słów”36.

Żądanie prawdy, wywierane na autorach podejmujących tematykę II wojny światowej, a w szczególności holocaustu, skutkowało nieufnością wobec wszelkich prób estetyzowania zapisu ${ }^{37}$. Pisanie o wojnie

\footnotetext{
${ }^{35}$ J. Wittlin, Pochwała kobiety piszqcej, „Wiadomości”1961, nr 25.

${ }^{36}$ T. Nowakowski, Przejście przez morze biało-czerwone, „Wiadomości” [Londyn] 1966, nr 26.

${ }^{37}$ Warto przytoczyć tu słynne votum nieufności wobec określenia „literatura holocaustu”, które sformułował Elie Wiesel: „nie istnieje i nie może istnieć nic takiego jak literatura holocaustu. Samo to pojęcie jest wewnętrznie sprzeczne. Auschwitz neguje każdą formę literatury tak, jak opiera się wszelkim systemom, wszelkim doktrynom [...]. Powieść o Auschwitz nie jest powieścią albo nie jest o Auschwitz. Sama próba
} 
Natalia Królikowska - Zofia Romanowiczowa. Zarys...

wymagało nie tylko talentu, ale i taktu ${ }^{38}$. W orbicie pisarskiej uwagi autorki Przejścia przez Morze Czerwone nie leży jednak odkrywanie uniwersalistycznych mechanizmów zbrodni, zła i okrucieństwa (jak w twórczości Zofii Nałkowskiej czy Tadeusza Borowskiego), a podążanie za ludzkim cierpieniem przybierającym różnorakie formy i wcielenia - głównie kobiece ${ }^{39}$. Romanowiczowa widzi na przykład i precyzyjnie odsłania mechanizmy winy i współodpowiedzialności ${ }^{40}$. Prowadzony z perspektywy zróżnicowanych poziomów zagrożenia - od mijania Niemca na ulicy po godzinie policyjnej czy uczęszczania na tajne komplety (w Szklanej kuli), przez osadzenie w więzieniu (w Łagodnym oku błękitu), aż po lęk przed demistyfikacją (w Na wyspie) wielotekstualny zapis opowiada o ludzkich doświadczeniach, posługując się wspomnieniami, narracją fikcjotwórczą, elementami reportażu, poetyckimi metaforami czy eseistycznym komentarzem. Wszystko po to, aby pokazać podmiot uwikłany we współuczestnictwo,

napisania takiej powieści jest bluźnierstwem" (cyt. za: A. H. Rosenfeld, Podwójna śmierć. Rozważania o literaturze Holocaustu, Warszawa 2003).

${ }^{38}$ Rozważając kwestie taktu w literaturze Hans Georg Gadamer zwracał uwagę na niebezpieczeństwo koniecznych niedopowiedzeń oraz na to, w jaki sposób takt i niedopowiedzenie kształtują przedstawienie i opowiadanie: „Niewyrazistość i niewyrażalność przysługują taktowi z samej jego istoty. Można coś powiedzieć taktownie. Zawsze jednak będzie to oznaczało, że coś się taktownie omija i się tego nie dopowiada. Pomijanie nie oznacza jednak odwracania spojrzenia od czegoś, lecz spoglądanie na coś tak, by się o to nie potknąć, lecz przejść obok. Dlatego takt dopomaga w utrzymaniu dystansu, pozwala uniknąć przeszkody, zbytniego zbliżenia" (Idem, Prawda i metoda, Warszawa 2004, s. 44).

${ }^{39} \mathrm{O}$ tym, w jaki sposób kategoria płci oddziałuje na teksty literackie, podejmujące temat wojny i okupacji, oraz w jaki sposób przyczynia się do reinterpretacji tradycyjnych, uniwersalistycznych (a więc w istocie androcentrycznych) ujęć i koncepcji literaturoznawców i historyków czytamy m.in. tu: M. Bogucka, Kwestia kobieca okiem historyka, „Teksty Drugie” 1993, nr 4/5/6; J. W. Scott, Women`s History, [w:] eadem, Gender and the Politics of History, Nowy Jork 1999; J. M. Ringelheim, The Unethical and the Unspeakable: Women and the Holocaust, „Simon Wiesenthal Center Annual” 1984, nr 1.

${ }^{40}$ O kwestii reprezentacji winy i współodpowiedzialności Polaków i Polek za zbrodnie II wojny światowej w literaturze polskiej czytamy m.in. tu: P. Czapliński, Prześladowcy, pomocnicy, świadkowie. Zagłada i polska literatura późnej nowoczesności, [w:] Zagłada. Współczesne problemy rozumienia i przedstawiania, P. Czapliński, E. Domańska (red.), Poznań 2009. 
z którego nie ma ucieczki - nawet po zakończeniu wojny czy poza granicami kraju. Jak w Skrytkach, utworze pozornie nie odwołującym się do wojennych doświadczeń, w których para głównych bohaterów dotkniętych głębokim kalectwem jedynego dziecka pustkę po jego „żywej” niegdyś obecności wypełnia codziennymi, praktycznymi obowiązkami, pełniącymi funkcję kompensacyjną. Konkretność i konieczność domowej krzątaniny zdaje się chronić bohaterów przed ciągłym doświadczaniem tragedii, która ich dotknęła, odciąga ich uwagę od tragedii. Choć małe, codzienne zwycięstwa są czymś niepodważalnym, znanym i oswojonym - w przeciwieństwie do katastrofy spadającej nagle i niespodziewanie na szczęśliwy dotąd dom. Marta Wyka twierdzi nawet, że „tym właśnie pasowaniem się z codziennością chcieliby oni swój los wyciszyć, czy nawet - zbuntować się przeciw niemu" 41 . Na gruncie poetyki opisy codziennych czynności, kobiecego „krzątactwa” nie są zwyczajowym, pamiętnikarskim życio-pisaniem. Pełnią one ważną funkcję egzystencjalną. Według filozofki Jolanty Brach Czainy stanowią podstawę istnienia, świadczą o naszym zakorzenieniu w codzienności ${ }^{42}$. U Romanowiczowej opisy te pełnią dodatkowo funkcję narracyjną - przemieszczają, odwlekają właściwe opowiadanie. Jak zauważa Alice Catherine Carls: „Szczegóły dotyczące obowiązków domowych, przygotowania posiłków lub innych przyziemnych prac dostarczają parawanu, poza którym kulminacyjny punkt historii może być wyrażony" 43 .

To, co stereotypowo bardziej „kobiece” w powieściach Romanowiczowej, to konfesyjny charakter jej twórczości, daleki jednak od naiwnych form pamiętnika czy dziennika intymnego, a więc form należących do literatury użytkowej. Introspekcyjność omawianej prozy jest funkcją poszukiwań dwudziestowiecznej powieści, której kierunek wyznacza wyjście od fabuły, przejście przez niefabularność, aż do

${ }^{41}$ M. Wyka, Zapomniana sztuka fabuły, „Pismo” 1983, nr 1/2.

${ }^{42}$ J. Brach-Czaina, Szczeliny istnienia, Kraków 1999.

${ }^{43}$ A. C. Carls, Reżyser, filozof, świadek. Estetyka złamania w utworach Zofii Romanowiczowej „Archiwum Emigracji” 2001, z. 4. 
Natalia Królikowska - Zofia Romanowiczowa. Zarys...

afabularności, w której zdarzenie zastąpione jest opowiadaniem ${ }^{44}$. Reguły narracyjnych rozwiązań quasi-autobiograficznych powieści Zofii Romanowiczowej ogniskują rozwój fabuły wokół losu głównej bohaterki, rozumianej jako figura w pewnym stopniu uobecniająca nie tylko implikowaną, ale i biograficzną autorkę45. Sama Romanowiczowa upatrywała źródeł literackości w szeroko rozumianym biografizmie właśnie, twierdząc $\mathrm{w}$ wywiadzie udzielonym Stanisławowi Beresiowi:

Oczywiście, pisanie zawsze opiera się o biografię. Ale do tej biografii należałoby przecież włączyć rzeczy, o których na ogół się nie myśli: np. lektury, wysłu-

${ }^{44}$ Taki kierunek przemian wyznaczył w swojej książce Bogdan Owczarek, podsumowując spostrzeżenia literaturoznawstwa dotyczące dwudziestowiecznej ewolucji sztuki opowiadania. Doszedł do następujących wniosków: „Literatura jest szczególną dziedziną funkcjonowania opowiadania. Demonstruje ona zazwyczaj jego stronę niespokojną, innowacyjną i nieprzewidywalną, pozwala na dziwaczne z nim próby i eksperymenty, nie wyklucza wreszcie rozwiązań chybionych i błędnych. Dzięki literaturze odradza się nieustannie właściwa sztuka opowiadania" (Idem, Poetyka powieści niefabularnej, Warszawa 1999, s. 10).

${ }^{45}$ Henryk Markiewicz, przytaczając dwudziestowieczne rozważania teoretycznoliterackie nad identycznością bądź nieidentycznością autora i narratora, zwraca uwagę, jak opinie badaczy zatoczyły koło, wychodząc od stanowczej dezidentyfikacji z początku wieku (K. Friedemann), przez myśli mniej radykalne (F. Stanzel), aż do powrotu w latach siedemdziesiątych, kwestii związanych z podmiotowością w literaturze i dowartościowaniem kategorii autora. Sam Markiewicz zajmuje, w tej swoiście niekonkluzywnej dyskusji, stanowisko pośrednie, rozdzielając wypowiedź narracyjną na asertowaną i nieasertowaną: „Od autora zewnętrznego, który jest realnie istniejącą osobą psychofizyczną, odróżniamy autora ujawniającego się w samej wypowiedzi, a ściślej, ujawnianego w niej przez działania interpretacyjne czytelnika lub badacza. Autor ten jest zazwyczaj na początku lub na końcu tekstu indywidualnie nazwany. Traktować go można rozmaicie: czynnościowo - jako podmiot dokonywanych kolejno operacji tekstotwórczych, systemowo - jako korelat reguł urzeczywistnionych w wypowiedzi, wreszcie personalnie - jako osobowość implikowaną przez właściwości tej wypowiedzi, a czasem także wprost charakteryzowaną przez informacje autoprezentacyjne. Osobowość ta ujmowana jest w powiązaniu z cechami znamionującymi autora wewnętrznego wcześniejszych utworów sygnowanych tym samym nazwiskiem - jako ich kontynuacja, modyfikacja lub zaprzeczenie. Może ona oczywiście różnić się od osobowości autora zewnętrznego zrekonstruowanej na podstawie innych manifestacji - np. zachowań w kontaktach osobistych czy korespondencji" (Idem, Autor i narrator, [w:] Prace wybrane, S. Balbus (red.), t. 4, Kraków 1996, s. 92). Por. też: H. Markiewicz, Teorie powieści za granicq. Od poczq̨tków do schyłku XX wieku, Warszawa 1995, s. 432 i nast. 
chane zwierzenia, itp. [...]. W Łagodnym oku błękitu odnajdzie pan historię autobiograficzną o tyle, że w znanych mi z autopsji więzieniach umieściłam wydarzenia, które opowiedziała mi tutaj w Paryżu moja koleżanka z Ravensbrück - Aga Glinczanka46.

Najbardziej radykalnym jak dotąd sprzeciwem wobec konwencjonalnego pisarstwa kobiecego było - jak można się domyślać znane Romanowiczowej ${ }^{47}$ - sformułowane w latach 70. przez Helen Cixous écriture féminine, czyli pisarstwo utopijnie ujmowane przez pryzmat seksualności i cielesności, ukształtowane pod wpływem ówczesnej myśli strukturalistycznej i feministycznej i współtworzone przez Julię Kristevę i Lucy Irigaray. Znaczenia ich pracy nie wolno dziś kwestionować, jednak potencjał innowacyjności kobiecego pisarstwa Romanowiczowej tkwi w czymś zupełnie innym. Po pierwsze, poetyka jej powieści wydaje się być dużo bardziej niejednoznaczna, w sposób twórczy przekraczająca kulturowo skonstruowany rozdźwięk między abstrakcyjnym rozumem a somatycznym i zmysłowym doświadczaniem. Po drugie, jeśli mówić już o ucieleśnionym doświadczeniu w utworach Romanowiczowej, to jego realizacja przebiegałaby wzdłuż osi wyznaczonej przez pamięć, przestrzeń i czas, czego najjaskrawszym przykładem jest narkolepsja, w trakcie ataków której Maria, bohaterka $\mathrm{Na}$ wyspie przenosi się do odległych historycznie i geograficznie miejsc.

Sama Romanowiczowa nie identyfikowała się z żadnym z nurtów literackich czy filozoficznych, umiejscawiając się zwykle w pozycji

\footnotetext{
${ }^{46}$ St. Bereś, Fałdy czasu, „Odra” 1990 nr 1, s. 12.

${ }^{47} \mathrm{~W}$ rozmowie ze Stanisławem Beresiem pisarka kilkakrotnie posługuje się cielesną i seksualną retoryką spod znaku écriture féminine. Opowiadając o swoich inspiracjach mówi: „byłoby dla mnie rodzajem nieuczciwości pakowanie do moich książek czegoś, czego nie znam, co nie wypisało się na mojej skórze [podkr. - N. K]”. W dalszej części wywiadu znajdujemy też taką wypowiedź pisarki: „Ostatecznie rzeczywiście mogłabym kazać swojej bohaterce spotkać kogoś, kto właśnie przyjechał z Polski, mogłabym wymyślić również jakieś inne sytuacje...ale czy to byłoby szczere? Jak by to powiedzieć? Dla mnie byłoby to tak, jakbym zaczęła pisać swoje książki w rodzaju męskim [podkr. - N. K.]” (St. Bereś, Przypadek, czyli prawdziwa fikcja, „Fraza” 2002, nr 3, s. 113).
} 
konserwatystki, której bliżej do kanonu utworzonego przez Harolda Blooma niż przez badaczki feministyczne. Włączanie Zofii Romanowiczowej w obręb pisarstwa kobiecego niesie więc ryzyko pewnego upodrzędnienia jej pisarstwa względem pisarstwa w ogóle. Nie wolno jednak pomijać roli perspektywy kobiecej tej twórczości, ponieważ bez wątpienia jest ona strategicznie i epistemologicznie istotna. Fakt odmienności (czy to płciowej, czy narodowej) jest zawsze upolityczniony (nawet wbrew wyraźnym intencjom autorki), a w przypadku Romanowiczowej także - transgresyjny. Jej pisarstwo jest demistyfikacją i przekroczeniem tego, co nawykowo, bezwiednie i bezrefleksyjnie zwykliśmy wiązać z pisarstwem kobiet. Dlatego konieczne jest wyjście poza stereotypizujące podejście do jej twórczości oraz do stosowanych przez nią praktyk teoretycznoliterackich (w szczególności tych, które oparte są na eksperymencie i innowacji), a także dostrzeżenie w nich potencjału znaczenia dla polskiego literaturoznawstwa. Dlatego trzeba znaleźć estetyczne - a nie społeczne czy polityczne - uzasadnienie na powrót jej twórczości do kanonu, uwzględniając przy tym fakt, że zarówno pojęcie wartości literackiej jest relatywnym, zmiennym historycznie konstruktem kulturowym, jak i same normy estetyczne wchodzą $\mathrm{w}$ dialektyczne relacje $\mathrm{z}$ wartościami społecznymi, politycznymi czy etycznymi. Trudno więc oddzielić immamentne cechy samego dzieła od powstających wokół niego niezależnych dyskursów. Wielokrotnie przytaczane przez literaturoznawców zdanie Roberta Escrapita o tym, że „literatura jest literaturą jedynie wtedy, gdy jest cytowana"48, jest szczególnie ważne przy badaniu twórczości niegdyś czytanej, recenzowanej, tłumaczonej na inne języki, później niemal całkowicie zapomnianej, a obecnie - przywracanej historii literatury.

${ }^{48}$ R. Escrapit, Literatura a społeczeństwo [w:] W kręgu socjologii literatury. Antologia tekstów zagranicznych, wstęp i oprac. A. Mencwel, Warszawa 1977, t. 1, s. 222. 


\section{Recepcja}

Prześledźmy dzieje krytycznej recepcji utworów prozatorskich Zofii Romanowiczowej, poczynając od jej debiutu w 1956 roku, a kończąc na pracach najnowszych. Jest to niezwykle ciekawe, ponieważ jak twierdzi Michał Głowiński:

Problemy, które powstają przy analizowaniu recepcji dotyczą w tym samym stopniu struktury dzieła literackiego, co wyobrażeń artystycznych odbiorców, systemu wyznawanych przez nich - świadomie bądź nieświadomie - wartości ${ }^{49}$.

Artykuły krytyczne dotyczące twórczości pisarki dzielą się na te synchroniczne - pisane w trakcie ukazywania się kolejnych tytułów i diachroniczne, pisane po zaprzestaniu przez Romanowiczową aktywności twórczej. Dominantą tekstów należących do grupy pierwszej jest dyskurs, związany środowiskowo $\mathrm{z}$ paryską emigracją, podejmowanymi przez nią tematami i podnoszonymi problemami. Dominantą drugich, bardziej antropologicznych, a szerzej, humanistycznych, powoli dochodzący do głosu dyskurs kulturowy, badający zagadnienia związane z tożsamością czy rodzajem dyskursu. Już w 1975 roku Józef Wittlin ostrzegał przed zbyt upraszczającym szeregowaniem pisarzy, zapewniając publiczność zebraną na spotkaniu z autorką Sono felice o tym, iż:

Zofia Romanowiczowa byłaby doskonałą powieściopisarką nawet wówczas, gdyby jako młodziutka Zosia Górska spędziła lata ostatniej wojny na wolności, w domu rodziców, w Radomiu, a nie w Ravensbrück, oraz innych kacetach. Podobnie jak Sołżenicyn byłby świetnym pisarzem nawet gdyby tylu lat życia nie spędził w sowieckich łagrach. Nie każdy kacetnik czy łagiernik wychodzi z obozu pisarzem. Trzeba to od razu powiedzieć, żeby uniknąć nieporozumień. A nieporozumienia powstają z naszych skłonności do ułatwień. Przylepi się do pisarza jakaś naprędce zrobiona etykietka - i to już na amen. Trudno ją potem odkleić $[. ..]{ }^{50}$.

${ }^{49}$ M. M. Głowiński, Konstrukcja a recepcja. Wokół „Dziejów grzechu” Żeromskiego, [w:] Idem, Gry powieściowe, Warszawa 1973, s. 215.

${ }^{50}$ J. Wittlin, Sono felice..., „Wiadomości”1975, nr 73. 
Natalia Królikowska - Zofia Romanowiczowa. Zarys...

W 1989 roku Wittlinowi wtórował Józef Bujnowski, komentując przyznanie Romanowiczowej nagrody Związku Pisarzy Polskich na Obczyźnie następująco:

\begin{abstract}
Dorobek ten [pisarski Romanowiczowej - N.K] stanowi głównie powieściopisarstwo, zaliczane powierzchownie do tzw. literatury obozowej. Występują niewątpliwie $\mathrm{w}$ tej bogatej twórczości reminiscencje wojenne i obozowe o większym lub mniejszym natężeniu. Niektóre urastają do pełnych kompozycji książkowych i stają się dokumentarnym przekazem autentycznych przeżyć. Niektóre biorą owe przeżycia tylko za punkt wyjścia lub margines. Ponad nimi wznosi się konstrukcja zagadnień ogólnoludzkich, wiecznych, ogarniających całą sztukę pisarską wszystkich czasów 51,52 .
\end{abstract}

Doświadczenie obozowe jest dla Romanowiczowej czymś więcej niż doświadczeniem historycznym, jest matrycą losu człowieka, modalnością wiszącej nad nim, nieuchronnej katastrofy, w przeżyciu której tkwi siła i mądrość istoty ludzkiej. Sama pisarka jasno wyjaśniła to przy okazji swojej wizyty w Nowym Jorku w rozmowie z Krystyną Wojtasik:

Jeśli jeszcze raz wspomniałyśmy tematykę okupacyjną - mówi Romanowiczowa - to chciałabym zaznaczyć, że mnie, jako pisarce, więzienie i obóz dały bar-

${ }^{51}$ J. Bujnowski, Niektóre uwagi o piśmiennictwie Zofii Romanowiczowej, „Pamiętnik Literacki" 1989, z. 14.

${ }^{52} \mathrm{O}$ tym, jak mocno upraszczająca etykieta literatury obozowej przylgnęła do twórczości Romanowiczowej świadczy chociażby opublikowany w 2004 roku szkic Doroty Mazurek, w którym autorka powiela schemat analityczny, funkcjonujący od lat wśród badaczy, podejmujących temat twórczości Zofii Romanowiczowej. W artykule czytamy: „Twórczość Z. Romanowiczowej powstała na bazie jej biografii wojennej wpisuje się w bogaty nurt literatury lagrowej i więziennej, będącej świadectwem okrucieństw totalitaryzmu czasów II wojny światowej. Teksty literackie pisarki bezpośrednio poświęcone tej problematyce mają formę fabularyzowanych dokumentów, łącząc $\mathrm{w}$ sobie łatwo czytelne wątki autobiograficzne i dokumentalne $\mathrm{z}$ elementami fikcji literackiej. Romanowiczowa buduje konwencję literacką, którą można określić jako fabularyzowane świadectwo. Autobiografizm w twórczości Zofii Romanowiczowej jest silnie rozbudowany, a chociaż często bywa maskowany konwencją fikcji fabularnej, najbliższy jest w charakterze świadectwu" (eadem, Kobieta i wojna. O twórczości Zofii Romanowiczowej, [w:] Kobieta w literaturze i kulturze, D. Mazurek (red.), Lublin 2004, s. 160). 
dzo wiele. To samo mogłoby dotyczyć każdej innej katastrofy, np. trzęsienia ziemi czy pożaru hotelu. Chodzi o sytuację $[\ldots]^{53}$.

Dlatego twórczość Romanowiczowej musi być interpretowana w szerszym niż tylko wojennym kontekście, ukazując dzieje jej bohaterek jako jednostek ludzkich dotkniętych, bardziej uniwersalną niż wojna, katastrofą. Romanowiczowa jest z pewnością orędowniczką nowego humanizmu, dla którego katalizatorem stała się wojna. Dla niej samej, a także dla wielu jej bohaterek, czas spędzony w obozie był czasem próby, z którego człowiek wyszedł zwycięsko. Doprowadzając swoich bohaterów do sytuacji skrajnych, stawiając ich w położeniu bez wyjścia, Romanowiczowa dociera do ludzkich rezerw moralnych, jakie pozostają człowiekowi nawet wówczas, kiedy wszystko wydaje się być stracone. Przykładem jest chociażby formuła „Puść palce”, której pomysłodawczynią była Lucyna, bohaterka Przejścia przez Morze Czerwone. Po raz pierwszy słowa te padły, kiedy jej młodsza, mniej dojrzała i słabsza psychicznie przyjaciółka wdała się w bójkę o kawałek zgniłej brukwi. Od tej pory zasada „puść palce” stała się metaforą zachowania ludzkiej godności, niezależnie od sytuacji. Reguła ta została wyniesiona przez bohaterkę $\mathrm{z}$ obozu i stosowana również w świecie powojennym, w relacjach z ludźmi „zza drutów”, niejednokrotnie przynosząc okaleczonej kobiecie poniżenie, wynikające z niezrozumienia oraz z nieprzystawalności reguł obozowych do życia na wolności.

Początek działalności literackiej Romanowiczowej należy bez wątpienia uznać za udany. Jej debiutancka powieść (a może raczej zbiór opowiadań?) ${ }^{44}$ Baśka i Barbara spotkała się z bardzo dobrym przyjęciem krytyki - zarówno tej na wychodźstwie, jak i krajowej55. Emigra-

\footnotetext{
${ }^{53}$ K. Wojtasik, Dama polskiej literatury, „Tydzień Polski” 1975, nr 215.

${ }^{54}$ Kwestia gatunkowości Baśki i Barbary wymaga bardziej wnikliwego omówienia, które znajdzie się w kolejnych rozdziałach rozprawy.

${ }^{55}$ Zygmunt Markiewicz nazwał książkę „prawdziwą niespodzianką”, a Zdzisław Najder podniósł kwestie w niej poruszane do rangi zagadnień ogólnonarodowych (por. Literatura polska na obczyźnie, T. Terlecki (red.), t. 1., s. 148; Z. Najder, Dziecko i sprawa polska, „Twórczość” 1958, nr 4). W recenzjach krajowych znacznie bardziej
} 
Natalia Królikowska - Zofia Romanowiczowa. Zarys...

cyjna rzeczywistość została w niej ukazana w sposób umożliwiający szeroką akceptację społeczną, będąc przy tym ideologicznym i środowiskowym akcesem autorki. Zamysł konstrukcyjny oraz narracyjny tego i kilku innych utworów Romanowiczowej uruchamia taki proces lektury, który ewokuje ich odbiór jako tekstów wiarygodnych i nie do końca fikcyjnych. Baśka i Barbara to powieść złożona z osiemnastu rozdziałów, opisujących po kolei przyjście na świat córki bohaterki, jej pierwsze miesiące życia, aż do - kończących utwór - szóstych urodzin Basi. Największym walorem tej książki jest opisanie początku bytu i formowania się podmiotu - począwszy od ciąży, przez poród, aż po przyjście dziecka na świat i jego pierwsze lata życia. Jak pięknie zauważył Henryk Bereza: „Wokół tajemnicy końca zamyka się połowa wielkiej sztuki świata, tajemnica początku jest do dziś w sztuce dziewiczym lądem, bo jest to ląd niedostępny dla mężczyzny"56. W pierwszym rozdziale, zatytułowanym Pqki na kasztanach, autorka próbuje zgłębić tajemnicę poczęcia i przyjścia na świat nowej istoty. Metafora zawarta w tytule rozdziału odwołuje się do pierwszych sygnałów rodzącego się życia w przyrodzie. Oczekiwanie na dziecko jest więc oczekiwaniem na wiosnę, na przebudzenie się życia po koszmarze wojennej zimy. Jak zauważa Irena Burzacka:

Dla Romanowiczowej, byłej więźniarki Ravensbrück i Neu Rohlau, macierzyństwo było sui generis powrotem do normalności i przyniosło tak dużą skalę doznań, że pisarka uczyniła je tematem swego debiutu książkowego ${ }^{57}$.

Temat macierzyństwa jako pomostu przerzuconego przez życie, wyprowadzającego z ciemnej nocy do jasnego poranka Romanowiczowa

koncentrowano się na językowo-wychowawczych aspektach utworu, niż jego walorach artystycznych (por. K. Nastulanka, Edukacja Barbary, "Nowa Kultura” 1958, nr 20; R. Rosiak, Kto wygra: polska Baśka czy francuska Barbara?, „Kamena” 1958, nr 5; T. M. Pasierbiński, Dzieci bez ojczyzny, „Życie Warszawy” 1956, nr 232). Wyjątkiem jest zaś recenzja Zbigniewa Pędzińskiego (Idem, Baśka i Barbara, „Nowiny Literackie i Wydawnicze" 1957, nr 10-11).

${ }^{56}$ H. Bereza, W hołdzie marzeniom, „Twórczość” 1961, nr 8.

${ }^{57}$ I. Burzacka, Macierzyństwo jako temat literacki. O „Baśce i Barbarze” Zofii Romanowiczowej, [w:] Modernizm. Zapowiedzi, krystalizacje, kontynuacje, A. Grzelak, M. Kurkiewicz (red.), Bydgoszcz 2009, s. 523-540. 
zrealizuje również w kolejnych powieściach, Grobach Napoleona i Ruchomych schodach oraz (epizodycznie) w Łagodnym oku błękitu. Niewątpliwa afirmacja życia i wrażliwa percepcja świata dominująca w tych powieściach ma również swój wynikający z matczynych obaw i trosk narratorki rewers. Mimo że wyczekiwane i jak najbardziej naturalne macierzyństwo, którego metaforą są tytułowe pąki na kasztanach, podszyte jest, jak każde jeszcze nieprzeżyte doświadczenie, olbrzymim lękiem. Jego obrazem staje się opis błądzącej po plątaninie szyn lokomotywy, po odjeździe której ciemnieje niebo: „Niepokój, jaki wynika z tego obrazu, nocny, tajemniczy pejzaż korespondują z alarmem w organizmie matki. Pisarka ukazuje całą «maszynerię» bólu"58. Pomimo że tak różna od kolejnych powieści Baśka i Barbara, należąca według chronologii twórczości Romanowiczowej zaproponowanej przez Bielatowicza do okresu „odkrywania świata i rysunku z przyrody" ${ }^{59}$, to i ona podszyta jest charakterystycznym dla całej twórczości Romanowiczowej niepokojem. Badacz dodaje, że:

Opowiadania te należą wprawdzie do gatunku prozy realistycznej, ale nie kończą się na prostej afirmacji i opisie życia. Każde z nich to znak zapytania, więcej, niepokoju i trwogi, już nie o siebie tylko, ale o życie powiększone i przedłużone, podwojone, o siebie i dziecko60.

Co ciekawe, Romanowiczowa antycypuje w swoich utworach poświęconych macierzyństwu temat drugiego pokolenia, czyli dzieci ocalonych z holocaustu, noszących obciążenia psychiczne swoich rodziców, a więc - mówiąc metaforycznie - naznaczonych „blizną bez rany”61.

${ }^{58}$ Ibidem, s. 526.

${ }^{59}$ J. Bielatowicz, op. cit.

${ }^{60}$ Ibidem

${ }^{61} \mathrm{~W}$ przełomowym studium dotyczącym tego zagadnienia jego autorka - Helena Epstein uznała „drugie pokolenie” za odrębną grupę społeczną, naznaczoną nie tyle przez znajomość tragicznych doświadczeń, jakich doznali ich rodzice, co przez brak pamięci o traumatycznych przeżyciach. Opowieści dzieci ocalonych potwierdziły przypuszczenia o tym, jak holocaust negatywnie odbił się na dynamice i życiu rodzin, w których dzieci często doświadczały emocjonalnego dystansu i braku empatii ze strony rodziców przy jednoczesnej nadopiekuńczości (por. H. Epstein, Children of the Holocaust. Conversations with Sons and Daughters of Survivors, Nowy Jork 1988). 
Natalia Królikowska - Zofia Romanowiczowa. Zarys...

W Grobach Napoleona pada zdanie powtórzone w pewnym sensie w wymowie Skrytek: „Zmartwychwstańcy nie powinni płodzić”. Dlatego już nawet Baśkę i Barbarę nazwać można „książką trudnego macierzyństwa", bo jak zauważa Bielatowicz:

Nie jest to dzieło, jakby mogły wskazywać pozory, o budzeniu i kształtowaniu się świadomości dziecka, lecz o troskach matki, która w życiu własnym przeżyła grozę i matki wyrzuconej na obcy brzeg [...]. Opowiadania te są, tedy zapowiedzią następnego okresu, w którym autorka już wyzbędzie się naiwnego realizmu i znajdzie także własną formę 62.

Przyjemność i radość czytania dająca - jak to określił w jednej z recenzji Antoni Bogusławski - „odpoczynek od wynaturzeń modernizmu"63 - czyli to, co udało się Romanowiczowej zbudować w świecie przedstawionym Baśki i Barbary, nie mogło powtórzyć się w kolejnej powieści.

Przejście przez Morze Czerwone dalekie jest od prób ustabilizowania własnego horyzontu fikcji epickiej, kreując w zamian połamaną rzeczywistość świata wewnętrznego bohaterki-narratorki. Pierwsi krytycy i czytelnicy nazwali Przejście przez Morze Czerwone, to „Szczęśliwe zdarzenie literatury polskiej”64, nowoczesną antypowieścią, dostrzegając $w$ niej walor nowatorskiej narracji oraz innowacyjność rozwiązań formalnych. Jedna z najwcześniejszych analiz Przejścia..., autorstwa Bronisława Mamonia, lokuje je „na linii między Marcelem Proustem (daleka miniatura cyklu $W$ poszukiwaniu straconego czasu) a Nathalie Saurraute (powiązania w metodzie pisar-

W Polsce refleksję tę podjęła Barbara Engelking (por. eadem, Konsekwencje doświadczeń wojennych $w$ drugim pokoleniu [w:] tejże Zagłada i pamięć. Doświadczenie Holocaustu i jego konsekwencje opisane na podstawie relacji autobiograficznych, Warszawa 2001, s. 252-267) oraz pisarze i pisarki, m.in. Mikołaj Grynberg w tomie złożonym z przeprowadzonych przez siebie rozmów z dziećmi ocalałych, Agata Tuszyńska w osobliwej sadze rodzinnej, Bożena Umińska-Keff w literackim rozrachunku z matką oraz Magdalena Tulli (por. M. Grynberg, Oskarżam Auschwitz. Opowieści rodzinne, Wołowiec 2014; A. Tuszyńska, Rodzinna historia lęku, Kraków 2008; B. Umińska-Keff, Utwór o matce i ojczyźnie, Kraków 2008, M. Tulli, Włoskie szpilki, Warszawa 2011).

${ }^{62} \mathrm{~J}$. Bielatowicz, op. cit.

${ }^{63}$ A. Bogusławski, Mądrze i ładnie, „Dziennik Polski” 1956, nr 157.

${ }^{64}$ M. Czapska, Do samego dna doznań, „Tydzień Polski” 1961, nr 13. 
skiej)"65. Mamoniowi zdaje się wtórować Maria Czapska, tytułując entuzjastyczną recenzję drugiej powieści Romanowiczowej cytatem z Prousta66. Niezwykła forma Przejścia przez Morze Czerwone oraz poruszająca problematyka i sposób jej przedstawienia uczyniły z niej „jedną z najbardziej interesujących powieści ostatnich lat”67, a samą Romanowiczową „pierwszą damą polskiej literatury”68. Przejście... jest niewątpliwie jedną z bardziej udanych prób literackiego ujęcia tego, czym było doświadczenie obozowe, Agambenowska „aporia Auschwitz" 69 w dziejach polskiego piśmiennictwa, które (dzięki przekładom na język angielski, francuski i niemiecki) uzyskało również duży

${ }^{65}$ B. Mamoń, Strach przed drugim brzegiem, „Tygodnik Powszechny” 1961, nr 31.

${ }^{66}$ „Aller jusqu'au fond de sensation” („sięgnąć do samego dna doznań”) - zalecał Proust. To sięganie dna wyczuwa czytelnik na własnej skórze. Nić pajęcza, drążenie kornika - podobnie jak u Nathalie Sarraute. Coś jak wiercenie w bolącym zębie, rozdrapywanie, świerzbiącego liszaju - do krwi, do krwi" (M. Czapska, Do samego dna doznań, „Tydzień Polski” 1961, nr 13).

${ }^{67}$ Z. Kozarynowa, Udział Polaków w literaturach zachodnich, [w:] Literatura polska na obczyźnie, T. Terlecki (red.), t. 1, s. 516.

${ }^{68}$ To określenie Józefa Wittlina, sformułowane w jednym z artykułów prasowych, będącym zapisem wprowadzenia do spotkania z autorką w nowojorskim Instytucie Naukowym (por. J. Wittlin, Młoda proza emigracyjna [w:] „Wiadomości” Londyn 1959, nr 34, s.1). Samo spotkanie amerykańskiej publiczności z Romanowiczową opisała w „Tygodniu Polskim” Krystyna Wojtasik: „Zainteresowanie jej osobą było tak duże, że nowojorski Instytut Naukowy «pękał w szwach», zabrakło krzeseł, niektórzy siedzieli na schodkach lub po prostu na podłodze. Powitali ją prof. Tadeusz Gromada i prof. Frank Mocha, przedstawił pisarz i poeta Józef Wittlin. Kiedy oficjalna część spotkania się skończyła, trudno było docisnąć się do pisarki, zamienić więcej niż kilka słów” (K. Wojtasik, Dama polskiej literatury, „Tydzień Polski” 1975, nr 215).

${ }^{69}$ Pomimo bogactwa literatury obozowej, mało jest tekstów w polskiej literaturze, które posiadają, poza walorem dokumentarnym i faktograficznym, walor wysokoartystyczny. Ciężar problemu przedstawienia okrucieństw lagrowej rzeczywistości wpływał zwykle na formę literacką, ponieważ w krytyce literackiej panowało przekonanie, iż - jak stwierdził Przemysław Czapliński - „teksty o holokauście są przekazami pełniącymi inne funkcje niż estetyczne" (Idem, Zagłada jako wyzwanie dla refleksji o literaturze, „Teksty Drugie” 2004, nr 5). Dlatego większość tekstów, dotyczących holocaustu oceniana była często tylko z "moralnej” perspektywy, wytykanie braków warsztatowych w kontekście świadectw uważano za nieetyczne. Por. idem, Zagłada jako wyzwanie dla refleksji o literaturze, „Teksty Drugie” 2004, nr 5. 
Natalia Królikowska - Zofia Romanowiczowa. Zarys...

\section{rozgłos na Zachodzie ${ }^{70}$. Aileen Pippett w recenzji opublikowanej w „New York Times Book Review” stwierdziła:}

Although intensely introspective, deliberately introducing a confusion of superimposed images in broken time sequence, Passage Through the Red Sea is full of sharp detail. There have been many firsthand accounts of concentration camp life but none more cruelly clear than these recollections of a waif whose only protection against the senseless, automatic brutality of her jailers is a borrowed pride to endure. The long, sinuous rhytms of the prose, magnifi-

${ }^{70}$ Europejskie sukcesy francuskiego przekładu pióra Jerzego Lisowskiego referowano obszernie m.in. w londyńskich „Wiadomościach": „W «Figaro Littéraire» z 27 maja br., Luc Estang pisze: «Jeżeli nowość tematu, lub przynajmniej nowy sposób przedstawienia go, jeżeli bogactwo wewnętrzne, złożone z licznych wątków wpływających na siebie wzajemnie, jeżeli mądrość analizy, subtelność spostrzeżeń, powściągliwość wyostrzonej wrażliwości, oszczędność w najbardziej patetycznych opisach, jeżeli wreszcie rygorystyczne panowanie nad opowieścią są pewnymi kryteriami, nie ma obawy bym się mylił. Przejście przez Morze Czerwone jest małym arcydziełem”. W recenzji Alaina Bosquet («Combat» z 1 czerwca br.) czytamy: «Niemożności porozumienia się dwu kobiet, które przeżyły te same cierpienia, Zofia Romanowicz nadaje pozór poetyczny, pełen prawdziwego dźwięku.. Wszystko tu jest w półcieniach, w aluzjach, w delikatnych gestach». W «Information» z 10 czerwca br. M. P. C. nazywa Przejście przez Morze Czerwone jedną z «najdziwniejszych i najpiękniejszych książek», jakie się ukazały w ostatnim okresie, i dodaje że po autorce można się wiele spodziewać. Noelle Loriot w «Nouveau Candide» z 8-15 czerwca br. zaznacza że «tych którzy we Francji zdążyli już przeczytać Przejście przez Morze Czerwone przejęło do głębi oszczędne piękno tej książki». W antwerpskiej «Métropole» z 28 maja br. Frédéric Kiesel podnosi że «nieustanne manipulowanie flashbackiem, któremu oddaje się ta niezwykle kulturalna pisarka, jest rzeczą bardzo niebezpieczną, a jednak ani na chwilę nie mamy wrażenia zbytecznej wirtuozerii technicznej. To dlatego, że wypływa ono z niczym innym nie dającego się zastąpić nacisku wewnętrznej konieczności». W brukselskiej «Revue Nouvelle» z 15 lipca br. Franz Weyergans podkreśla, że powieść Romanowiczowej świadomie «zrywa ze zwyczajami powieściopisarzy, którzy opowiadają jakąś fabułę. Nie brak w niej fabuły, wręcz przeciwnie. Ale wprowadzona jest ona w opowieść w tak szczególny sposób, tak bardzo splątana z życiem narratorki, że lektura musi być bezustannym odkrywaniem. Wszystkie książki o pewnej wartości zakładają bezsprzecznie współudział czytelnika, ale dzieje się to za pomocą wyraźnego założenia. Tutaj samo założenie jest sekretne, tak że praca jest podwójna. Niechże czytelnik przyjmie to ostrzeżenie: będzie musiał czuwać, aby niczego nie uronić, niczemu nie dać się wymknąć. Za to nagroda jest wielka. Na kartkach tej krótkiej powieści zbiera się materiał na trzy tomy. Myślę, że nie jest to najmniejsza pochwała», (O powieści Zofii Romanowiczowej, „Wiadomości” 1961, nr 33). 
cently translated by Virginia Peterson, carry the echoes of pain through corridors of receding time, giving the book a somber and melancholy beauty ${ }^{71}$.

Przejście przez Morze Czerwone daje, przy użyciu eksperymentów formalnych, kliniczny obraz egzystencji bezsensownej. Jest to portret kobiety o pustym wnętrzu, opuszczonej i samotnej, kobiety w stanie moralnej i emocjonalnej atrofii, która o popełnionej przez siebie zbrodni mówi następująco:

To, co się stało, stało się przeze mnie, materialnie ja byłam tego sprawcą i gdyby ktoś mnie sądził, zasądziłby mnie jako winowajcę, ale czy może być mowa o winie, gdy winą jest gest, bezsilny sam w sobie, właściwie przypadkowy, i gdy dysproporcja pomiędzy tym gestem a jego konsekwencjami jest tak olbrzymia, że biorąc na siebie według zwykłego porządku rzeczy odpowiedzialność, utożsamiłabym się z siłą, która także i mnie kiedyś zgniecie ${ }^{72}$.

Romanowiczowa, podobnie jak przywoływany przez krytyków patron jej twórczości Albert Camus w kanonicznym dla egzystencjalizmu Obcym, nie docieka przyczyn społecznych czy historycznych pojawienia się takiego stanu ducha i takich odczuć. Tak jak Camus „poświęci się jedynie jego psychologicznej analizie, ażeby stworzyć w rezultacie nową postać literacką, nowy typ bohatera"73.

Strategię tę Romanowiczowa rozwinie w swojej kolejnej mikropowieści pod tytułem Słońce dziesięciu linii. Jej główna bohaterka, podobnie jak narratorka Przejścia, jest osobą okaleczoną. Rana za uchem jest skutkiem eksperymentów medycznych dokonywanych na niej w obozie koncentracyjnym. Jej opowieść krąży wokół rany, która nijak nie daje się zakryć. W tym sensie znamię Niny jest mitotwórcze, kreuje opowieść zawartą w tej niedługiej powieści. Temat rany jest wielokrotnie powtarzany, wskutek czego rana się mnoży. Zwielokrotnienie rany nie przybliża jednak do jej oswojenia, do pogodzenia się $\mathrm{z}$ nią, ponieważ jej istota tkwi w dwuznaczności, polegającej na ustawicznej próbie jej zakrycia przy jednoczesnej niemożności zapomnie-

\footnotetext{
${ }^{71}$ A. Pippett, Faithless Lucile, „New York Times Book Review” 1962, nr 15, s. 53.

${ }^{72}$ Przejście przez Morze Czerwone, s. 170.

${ }^{73}$ J. Kossak , Wstęp [w:] A. Camus, Eseje, Warszawa 1971, s. 24.
} 
Natalia Królikowska - Zofia Romanowiczowa. Zarys...

nia o niej. Krążąc wokół rany, czyli wokół tego, co najbardziej dolegliwe, co fizyczne, a przez to realne, Romanowiczowa powtarza katastrofę, ukazuje jej otwartość, niemożność zakończenia. Rana jest też obrazem-ekwiwalentem zdekomponowanej, uszkodzonej osobowości. Pisanie o ranie jest być może imaginacyjną próbą zamknięcia tego, czego zamknąć nie sposób. Rana jest symbolem ludzkiej ułomnej i niedoskonałej cielesności. Jest też śladem opresji, miejscem, przez które w jednostkową i niezależną podmiotowość wkroczył drugi człowiek, sprawując nad nami władzę i raz na zawsze pozbawiając nas swojej integralności tożsamej z zamknięciem w powłokach ciała. Rana staje się znakiem reifikującym (w rozumieniu Sartre'a) ${ }^{74}$, wywłaszczającym $\mathrm{z}$ normalności na wieczne wygnanie inności, wyrażone sentencją narratorki Słońca dziesięciu linii: „Byłam jak oni ale byłam różna"75. Kiedy zrozumiemy ranę jako metonimię ciała, wszelkie doświadczanie, każde „bycie w świecie” (zarówno fizyczne, jak mentalne) okaże się bolesne, a sytuacja bohaterki - jak zauważa Anna Łebkowska - „odbierana i ukazywana będzie poprzez ustawiczne zderzenia ze światem, poprzez metafory przestrzenne i dotykowe zarazem"76. Jak w przytoczonym dalej przez badaczkę początkowym fragmencie Słońca dziesięciu linii: „Byle gdzie, byle kiedy, ta myśl mnie dopada. Wciąż się o nią potykam, wciąż się o nią ranię"77. Swoją trzecią książką Romanowiczowa utrwaliła zdobytą wcześniejszymi utworami renomę. Jak odnotował w jednej z pierwszych recenzji powieści Paweł Zaremba:

Pierwsza, Baśka i Barbara, była sensacją literacką, której znaczenia nawet ckliwe pochwały nie zdołały osłabić. Widziałem w niej najlepsze dzieło literackie napisane po wojnie w języku polskim. Następna: Przejście przez Morze

${ }^{74}$ Por. A. Drwięga, Trzy wymiary cielesności w myśli Jeana Paula-Sartre'a, [w:] Idem, Ciało człowieka. Studium z antropologii filozoficznej, Kraków 2005.

${ }^{75}$ Słońce dziesięciu linii, s. 118.

${ }^{76}$ A. Łebkowska, Dotyk - piętno - ciało. O jednej powieści Zofii Romanowiczowej, [w:] Od polityki do poetyki. Prace ofiarowane Stanisławowi Jaworskiemu, C. Zalewski (red.), Kraków 2010, s. 240.

${ }^{77}$ Słońce dziesięciu linii, s. 11. 
Czerwone wprowadziła Romanowiczową do literatury światowej [...]. Teraz ukazało się Słońce. Książka krótka, napisana szybko, jednym ogromnym wyładowaniem talentu, w której każde zdanie drga wewnętrznym przeżyciem i koniecznością opowiedzenia przeżycia. W konstrukcji literackiej doskonała, pomimo tylu pułapek jakie pisarzowi stawia swobodna wędrówka po czasie przeszłym, po wspomnieniach, kłócących się o lepsze z opisem teraźniejszości. I przede wszystkim ogromnie prawdziwa ${ }^{78}$.

Wydana rok później powieść Szklana kula nie spotkała się z tak ciepłym przyjęciem krytyki. Włodzimierz Maciąg nazwał ją „elegią o latach wojny”, którą „czyta się z sympatią"79, z kolei Karol Zbyszewski zaliczył ją do kategorii książek, które „są chwalone, lecz są nie do czytania"80. Faktycznie, opowieść o umierającej Halinie jest w wielu fragmentach nazbyt tkliwa, liryczna i patetyczna, a przy tym nadmiernie autotematyczna. Rację ma Witold Olszewski, gdy twierdzi: „Romanowiczowa zbyt dobrze włada skomplikowaną formą nowoczesnej narracji, by w taki sposób przypominać czytelnikowi o formalnych walorach swego pisarstwa" ${ }^{81}$. Oddzielenie, a nawet w kontekście powieści poprzednich - rozszczepienie narratora od bohatera, a więc przejście od narracji autodiegetycznej do homodiegetycznej ${ }^{82}$, można interpretować jako eksperyment Romanowiczowej, próbę dojrzałego podmiotu do opisania samego siebie z poznawczego i emocjonalnego dystansu, próbę w tym przypadku niezbyt udaną. Interesujące jest to, że narratorka konstruuje „na oczach czytelnika” bohatera, konfrontując go z własnymi doznaniami. Przedmiot opisu narratorki (postać

\footnotetext{
${ }^{78}$ P. Zaremba, Słońce dziesięciu linii, „Orzeł Biały - Syrena” 1963, nr 26.

${ }^{79}$ W. Maciąg, Nowości prozy, „Życie literackie 1965, nr 9.

${ }^{80}$ K. Zbyszewski, Nastrój nie bije ze „,Szklanej kuli”, „Dziennik Polski i Dziennik Żołnierza" 1964, nr 301.

${ }^{81}$ W. Olszewski, Szklana kula, „Horyzonty” 1965, nr 104.

${ }^{82} \mathrm{~W}$ odniesieniu do zastosowania przez narratora gramatycznej formy pierwszoosobowej Gerard Genette wyróżnia dwa typy narracji: autodiegetyczną i homodiegetyczną. Kiedy narrator jest tożsamy z głównym bohaterem, mówimy o narracji autodiegetycznej, natomiast kiedy mimo zastosowania pierwszoosobowej formy gramatycznej narrator nie jest identyczny z bohaterem, wówczas mówimy o narracji homodiegetycznej. Por. P. Lejeuene, Pakt autobiograficzny [w:] Idem, Wariacje na temat pewnego paktu. O autobiografii, Kraków 2001, s. 24.
} 
Natalia Królikowska - Zofia Romanowiczowa. Zarys...

Haliny) wraz z rozwojem opowiadania coraz bardziej się upodmiotawia, a wyraźna na początku granica między bohaterką a narratorką zaciera się:

Ten świat, dostrzeżony po raz ostatni w jednym ułamku sekundy przez szparę płachty odwianej wiatrem, wydaje mi się czasem nowy, jakbym go sobie tylko wymyśliła lub świeżo wyczytała o nim w jakiejś monografii, a czasami mój własny, tak zupełnie własny i mój, jakbym nigdy stamtąd nie była wywieziona, jakbym to ja, a nie Halina, pozostała na ulicy zasypanej śniegiem, w kożuszku przytupując butami o wysokich wojennych, cholewach. A potem jakby moje, a nie jej ciało, ofiarowane w niebacznym, właściwie prowokującym ślubie („Boga się nie boisz, dziewczyno” - powiedziałaby, gdyby o tym się dowiedziała, babka...) to ciało odrzucone, nasze ciało zaczęło najpierw powoli, a potem z przerażającą szybkością psuć się i odpadać od kości83.

Wszystko to jest jednak zbyt ckliwe i naiwne. Opowiedziane w sposób zbyt nachalnie liryczny i wzruszający jak na autorkę genialnego Przejścia przez Morze Czerwone ${ }^{84}$.

Rehabilitacja pisarki nastąpiła jednak błyskawicznie. Opublikowany rok później zbiór opowiadań zatytułowany Próby i zamiary otrzymał m.in. nagrodę „Wiadomości” za najwybitniejszą książkę pisarza polskiego wydaną na emigracji w roku 1965. Warto przypomnieć, że Romanowiczowa była jedyną kobietą wśród nominowanych. Jeden z członków jury, Kazimierz Wierzyński, w następujący sposób uzasadniał swój wybór:

Fragmentaryczne, można by powiedzieć miniaturowe utwory Romanowiczowej, to jakby postrzępione nerwy nieszczęścia ludzkiego w kłębowisku ledwie dyszącego życia, martwiejące szczątki słów, uczuć, nadziei [...]. Wobec Przej-

\footnotetext{
${ }^{83}$ Z. Romanowiczowa, Szklana kula, s. 150-151.

${ }^{84}$ Warto zwrócić uwagę na opinię Konstantego Kota Jeleńskiego o czwartej powieści jego bliskiej przyjaciółki, który porównał Szklanq kulę do debiutu pisarki: „Dla powierzchownego czytelnika, Szklana kula Zofii Romanowiczowej może się wydać bliższa Baśki i Barbary niż jej obu poprzednich powieści" (K. A. Jeleński, Dwie szklane kule, „Na antenie” 1964, nr 10). Faktycznie, głównym bohaterem czwartej powieści pisarka ponownie uczyniła dziecko, ale dzieciństwo Haliny nie jest czasem beztroskiej zabawy małej Basieńki z słynnego debiutu, wyraźnie naznaczone jest już ono symboliczną „linią cienia”, cierpieniem, które łączy młodą Radomiankę z dorosłymi bohaterkami Przejścia przez Morze Czerwone i Słońca dziesięciu linii. Świat Basi to szklana kula sprzed wstrząsu, rzeczywistość Haliny to czas po wstrząsie.
} 
ścia przez Morze Czerwone książeczka Romanowiczowej jest mikrokosmosem, ale kondensacja tragedii ma siłę niebywałą. W niektórych miejscach nawet większą niż w powieści. W skrótach tych tym jaśniej wyraża się także wielki, mistrzowski artyzm pisarski Romanowiczowej, prawdziwa ozdoba naszej, nieco zaniedbanej pod tym względem prozy ${ }^{85}$.

\section{Wierzyńskiemu wtórował Juliusz Sakowski, zaznaczając iż:}

Mimo tytułu, który sugeruje, że chodzi o wątki do przyszłego dopiero rozwinięcia, o szkice które miały posłużyć do opracowania w większe całości, o zalążki przyszłych opowiadań czy powieści. Ta właśnie książka odbija od poprzednich i wznosi się ponad nie. W tamtych były próby nowych form, pomysłowość kompozycji, oryginalność wizji, niepokój twórczych poszukiwań. Tu, w krótkich kilkustronicowych opowiadaniach - nieraz suchych, oszczędnych relacjach - spokój spraw i rzeczy ostatecznych. Mówi się o nich w opanowanym artystycznie dojrzałym skrócie, z sugestywną siłą, świetnym językiem, tonem przejmująco stłumionym ${ }^{86}$.

Zupełnie inny jest kolejny utwór w artystycznym dorobku Romanowiczowej, której przecież, jak twierdzi Olszewski:

Ambicja pisarska nie pozwala na formalny zastój, w poszukiwaniu nowych sposobów wyrazu dla tych samych przeżyć zaczyna szukać obiektywnego punktu obserwacyjnego, epickiego tonu narracji ${ }^{87}$.

\section{Wielu krytyków uznało Łagodne oko błękitu za najlepsza powieść pisarki, okazała się ona również największym sukcesem komercyjnym autorki. Stanisława Jazówna stwierdziła:}

Piętnaście rozdziałów tej fascynującej powieści to piętnaście omal idealnie obrysowanych wymiarów okupacyjnego koszmaru, któremu talent, duże już po eksperymentach doświadczenie, piękna dojrzałość pisarska i wielki artyzm Romanowiczowej nadały cechy właśnie wstrząsająco ludzkie. Humanizując koszmar i dokonując przewrotu w dotychczasowej literaturze obozowej,

\footnotetext{
${ }^{85}$ Nagroda „Wiadomości” za najwybitniejszq ksiq̨żkę pisarza polskiego wydanq na emigracji w r. 1965. Laureatka: Zofia Romanowiczowa. Przebieg obrad jury, „Wiadomości" 1966, nr 30.

${ }^{86}$ J. Sakowski, Rok 1966. „Próby i zamiary” Romanowiczowej, „Wojna i sezon” Pawlikowskiego [w:] Idem, Dawne i nowe lata, Paryż 1970, s. 170.

${ }^{87}$ W. Olszewski, Zofia Romanowiczowa. Łagodne oko błękitu, „Horyzonty” 1968, nr 142.
} 
Natalia Królikowska - Zofia Romanowiczowa. Zarys...

Romanowiczowa doszła do dużego odkrycia. I to jeszcze dało powieści w podtekstach takie wysokie napięcie ${ }^{88}$.

Faktycznie, powieść ta jest na swój sposób przewrotna, tak na prawdę nie opowiada o tym, o czym pozornie opowiada. Paradoks ten dostrzega również Ewa Nowakowska:

\begin{abstract}
Nie jest to powieść o okupacji, martyrologii, tragicznej więziennej miłości i o tym wszystkim co na pozór wydaje się tak oczywiste i niepodważalne. Albo inaczej, już łagodniej: owszem, ta książka wyrasta z przeżyć okupacyjnych i to, o czym właśnie wspominałam jest w niej ważne, ale - jako punkt wyjścia, najbardziej zewnętrzna i oczywista warstwa. Jeżeli poprzestaniemy na niej, to Łagodne oko błękitu okaże się dla nas niczym więcej jak kolejnym przypadkiem wpisanym w martyrologiczny paradygmat, innymi słowy: jeszcze jednym utworem „o wojnie”. Popełnimy w ten sposób błąd niedoczytania tekstu i uronimy wiele spośród kryjących się w nim wartości ${ }^{89}$.
\end{abstract}

Narratorka Łagodnego oka błękitu pozornie całą uwagę skupia na perypetiach wojennej miłości Romea z Wehrmachtu i Julii z polskiej organizacji podziemnej. Prawdziwym tematem książki jest, pojęte bardziej uniwersalnie, zakazane uczucie oraz, jak zauważa Anna Jamrozek-Sowa: „dziwność [podkr. A. Jamrozek-Sowa] osobynauczycielki”90, z perspektywy której czytelnik „ogląda” wydarzenia. Na czym polega owa "dziwność” bohaterki? Tego Jamrozek-Sowa nie wyjaśnia. Posługując się w dalszej części wywodu kolejnymi eufemizmami, typu „skaza” czy „wada genetyczna”, autorka monografii próbuje zuniwersalizować odmienność portretowanej narratorki-bohaterki $^{91}$. Tymczasem panna Dominika w swoim nostalgicznym, mocno

\footnotetext{
${ }^{88}$ S. Jazówna, O „Łagodnym oku błękitu” Zofii Romanowiczowej, „Kronika” 1968, nr 49-50.

${ }^{89}$ E. Nowakowska, Eksperymenty Zofii Romanowiczowej, „Tygodnik Powszechny” 1988, nr 24.

${ }^{90}$ Ibidem

${ }^{91}$ Badaczka posługuje się tu, mniej lub bardziej świadomie, strategią „czytania na wskroś orientacji" (ang. reading across orientation - w skrócie cross-reading), polegającą na odczytywaniu wszelkiego typu znaków homoseksualności przez czytelnika egzystującego poza homoseksualnymi/gejowskimi czy lesbijskimi modelami tożsamościowymi (straight reader). Procedura ta ma charakter normalizujący oparty na „próbie neutralizacji «pozasystemowego» elementu znaczącego nienormatywnej sek-
} 
zsubiektywizowanym i osobistym, wręcz ekshibicjonistycznym wspomnieniu z pobytu w niemieckim więzieniu ewokuje dzieje swojego pożądania oraz satysfakcji erotycznej czerpanej z nawiązania pełnej napięć gry między kochankami a samą sobą. Jak zauważa Józef Bujnowski: „tok opowiadania jest równy, wyzuty z pasji, a przez to właśnie osiągający szczyty napięcia"92. Spojrzenie starej panny zawiera bowiem w sobie znacznie więcej niż tylko empatyczne zaangażowanie w losy współwięźniarki, posiada ono także, a może nawet w większym stopniu, charakter inwigilująco-penetrujący, u źródeł którego stoi ogólnoludzkie pragnienie wszechwiedzy, które (w wyjątkowych okolicznościach czy w skrajnych sytuacjach) może zamienić się w dążenie do stałej kontroli nad drugim człowiekiem.

Temat obsesji kontroli i władzy nad Innym, wywiedziony jak zawsze u Romanowiczowej z obozowych doświadczeń, rozwinięty został w kolejnej powieści. W Grobach Napoleona pisarka ponownie zawęża epicki horyzont narracji, ograniczając go do jednej długiej nocy, w trakcie której bohaterka dokonuje rozrachunku z własnym życiem. Pozornie nic się nie dzieje, minuty oczekiwania na przyjazd córki dłużą się w nieskończoność, od jednej drobnej czynności do drugiej. Niemalże cała akcja książki zostaje ponownie - tak jak w Słońcu dziesięciu linii czy w jeszcze wcześniejszym Przejściu przez Morze Czerwone, przeniesiona do wewnątrz psychiki głównej postaci. Groby Napoleona opowiadają o czasie skończonym, czasie „po”, w którym już nic się nie wydarza, można jedynie wspominać i analizować minione wypadki. W tym sensie jest to literacki przykład czasów współczesnych, czasów po końcu historii i wielkich narracji. W pisanym osiem miesięcy przed śmiercią wzruszającym liście starego mistrza do byłej uczennicy, proszącej o opinię o swojej najnowszej powieści (Groby

sualności, wpisania go w heteropatriarchalną siatkę znaczeń" (W. Śmieja, Dlaczego analiza zjawisk krytycznoliterackich wydaje się ważna i potrzebna przy opisie literatury homoseksualnej lat 80 [w:] Idem, Polska literatura homoseksualna po 1980, Katowice 2006).

92 J. Bujnowski, op. cit. 
Natalia Królikowska - Zofia Romanowiczowa. Zarys...

Napoleona) Melchior Wańkowicz dał świadectwo zmieniającego się wraz z przemijaniem kolejnych pokoleń pisarzy paradygmatu:

Droga Moja Zosiu, strasznie mi przykro, że z odpowiedzią zwlekałem tak długo, podczas kiedy pocztę załatwiam od ręki, wynikło to z jednej strony z chęci odpowiedzenia Tobie najrzetelniej, z drugiej strony z poczucia własnej bezsilności w ocenie książki. Mam już 82 lata, jestem schorowany i z trudem widzę, jak trudno mi jest nałamywać się do nowych konwencji. Z drugiej strony zostało mi poczucie pozwalające ocenić wartość tych rzeczy pisanych i malowanych w nowych konwencjach. Jakoś został mi nieomylny instynkt tego, czy rzecz taka, jeśli jej nawet nie obejmuję, jest wartościowa. W twoim wypadku zachodzi właśnie ta okoliczność (...)”93

Technika konstruowania wzrastającego napięcia oczekiwania zastosowana w Grobach Napoleona, nawiązuje niewątpliwie do Przejścia przez Morze Czerwone.

Jest tu jednak element nowy - dodaje Bujnowski - natręctwo motywów językowych, utartych i zapamiętanych fragmentów wierszy, pieśni, powiedzeń, wtrącanych jak gdyby siłą bezwładu, w normalny tok opowiadania, kojarzonych na nieraz bardzo odległych powiązaniach asocjacyjnych. Może na gruncie takich właśnie doświadczeń językowych oparła głębokie spostrzeżenie, że «Słowa zmieniają. Dobierając się, by przybliżyć prawdę, zwodzą94.

To ciekawe spostrzeżenie, szczególnie kiedy weźmiemy pod uwagę, iż Zofia Romanowiczowa należy do grona twórców, którzy traumę II wojny światowej odreagowywali aktywnością intelektualną i twórczą. Jednak jest to twórczość szczególna, będąca jak gdyby samej twórczości zaprzeczeniem, wynikającym z dojmującej niemożności komunikacji i tekstowego ukształtowania relacji pomiędzy pamięcią a inwencją̧95 - czego metaforą są tytułowe groby Napoleona, rodzaj pasjansa uporczywie układanego przez główną bohaterkę powieści,

${ }^{93}$ Cyt. za: Melchior M. Wańkowicz, List do Zofii Romanowiczowej z 25 I 1974, [w:] A. A. Ziółkowska, Na tropach Wańkowicza, Warszawa 1989, s. 59.

${ }_{94}$ J. Bujnowski, op. cit.

${ }^{95}$ Twórczość Romanowiczowej jest ilustracją problemu natury estetycznej i epistemologicznej zarazem, znanego literaturze czasów wojny - w jaki sposób zwerbalizować niewyrażalne, ekstremalne i eschatologiczne doświadczenie. Por. Literatura wobec niewyrażalnego, W. Bolecki, E. Kuźma (red.), Warszawa 1997. 
odgradzające ją od przytłaczającej rzeczywistości. Rozkładanie kart staje się natręctwem Wandy, prostą drogą w otchłań szaleństwa. Spędzona samotnie noc oczekiwania na powrót córki uruchamia lawinę wspomnień i rozrachunków z własnym życiem. Dzięki licznym reminiscencjom poznajemy dzieje Wandy - jej uwięzienie w obozie, ucieczkę, gwałt, pomoc Francuza, emigrację, macierzyństwo, śmierć partnera, inne związki z mężczyznami. Eugeniusz Romiszewski podsumowuje:

Tak skomplikowane przeżycia przewrażliwionej kobiety autorka ukazała swoim wypróbowanym sposobem od jej wnętrza, przy pomocy monologu wewnętrznego. I to moim zdaniem nie dało zamierzonego efektu. Jeżeli miało to być studium psychologiczne, to wymagałoby ukazania wypaczonej psychiki w przeciętnie normalnym a nie tak udziwnionym życiu [...]. Ten sam świetny warsztat pisarski, ale coś sztucznego zakradło się do tej powieści. Dobrze jednak, że Zofia Romanowiczowa dokonała jak gdyby eksperymentu. Można się spodziewać, że ta próba poprowadzi ku nowym osiągnięciom ${ }^{96}$.

Ludobójstwo i totalitaryzm pierwszej połowy XX wieku przesunęły ciężar rozważań humanistycznych ze zdewaluowanych autorytetów w stronę prywatnych, spersonalizowanych, nieraz nawet intymnych opowiadań. Taki sposób uspołecznienia najokrutniejszej nawet prawdy zobowiązywał wielu twórców do dokumentalistycznych ujęć. Berel Lang $\mathrm{w}$ pracy poświęconej problemowi przedstawiania zła zwraca uwagę na przeniesienie punktu ciężkości z opisu kategorii teoretycznoliterackich na kryteria prawdziwości w kontekście „literatury świadectwa":

Oprócz niezwykłego zaufania pisarstwa figuratywnego o nazistowskim ludobójstwie do rodzajów literackich wyraźnie przywołujących konwencje historyczne (dzienniki, wspomnienia), również strategie stosowane w bardziej tradycyjnych rodzajach i gatunkach literackich (powieść, poezja, dramat) odzwierciedlają tę tendencję [...]. Wspomniane środki literackie obejmują rewizję konwencji rodzajowych w kierunku dyskursu historycznego; autorskie wypowiedzi w ramach tekstu i poza nim, potwierdzanie historycznej podsta-

${ }^{96}$ E. Romiszewski, Groby Napoleona. Nowa powieść Zofii Romanowiczowej, „Na antenie" [Londyn] 1973, nr 121. 
Natalia Królikowska - Zofia Romanowiczowa. Zarys...

wy dla fikcji, obecne w tekście założenia zarówno o określonej wiedzy historycznej jak i moralnym punkcie widzenia ze strony zakładanego odbiorcy. Tego typu środki zdają się mieć tylko jeden cel: są nośnikiem autorytetu i przypuszczalnie realności - prawdy historycznej ${ }^{97}$.

W takim przypadku literatura staje się dłużniczką historii. Dlatego próba przekazania przez Romanowiczową osobistych doświadczeń obozowych jest czymś więcej niż świadectwem - jest próbą zmiany obowiązującego typu mówienia i opowiadania o wydarzeniach wojennych. Stary i nowy paradygmat świetnie ilustrują postaci Szymona i Teresy z Sono felice. Świadkiem, czyli tym, który ocalał, aby dawać świadectwo prawdzie, jest dokumentujący i wiecznie "chronometrujący”, Szymon"98. Jednak to nie on jest głównym bohaterem czy narratorem tej powieści. Protagonistką Sono felice jest niepisząca, wstydząca się przed swoim mistrzem własnej bierności, Teresa, symbol autentycznego podmiotu straumatyzowanego, którego doświadczenia nie poddają się kreacji fikcjotwórczej z dwóch powodów. Po pierwsze, nie istnieją żadne wzorce zachowań, którymi możnaby te doświadczenia objaśnić, ani żadna obiektywna i wspólna rzeczywistość, do której można by je odwołać. Po drugie, podmiot straumatyzowany nie opowiada. Andrzej Zieniewicz, analizując „pakt traumatyczny" jako jedną z odmian paktów autobiograficznych w dwudziestowiecznej literaturze, pisze:

Nawet gdy zaczyna mówić, nie stwarza opowiadania. Ponieważ rozbite ja ma strukturę niezrealizowanej opowieści. Właśnie nie-zrealizowanej, gdyż rozgrywanej w działaniu (acting out), uwikłanej w melancholię (w sensie Freudowskim) to znaczy w przymusy powtórzeń, we fragmentaryczność i fantazmatyczność relacji. Koszmar wypierany ze świadomości, tłumiony, nieopowiadalny ujawnia się w formach zastępczych, a że one nie docierają do istoty rzeczy, więc są obsesyjnie ponawiane. Strzępy, fragmenty, zautomatyzowane

\footnotetext{
${ }^{97}$ B. Lang, Przedstawianie zła: etyczna treść a literacka forma [w:] Idem, Nazistowskie ludobójstwo. Akt i idea, Lublin 2006, s. 138.

${ }^{98}$ Krytycy piszący o Sono felice zbyt mocno przykładali uwagę do faktu, że pod postaciami Szymona i Teresy Romanowiczowa opowiedziała część swojej biografii, kiedy to ważną w niej rolę odgrywał Melchior Wańkowicz. Por. M. Orski, $W$ pogoni za szczęściem. Zofia Romanowiczowa „Sono felice”, „Przegląd powszechny” 1997, nr 1.
} 
repetycje, którymi mówią ocaleńcy, są ponadto na antypodach elementarnej motywacji epickiej. Ponieważ epika ma przedstawiać, przybliżać świat, gdy relacja traumatyczna, przeciwnie - pragnie przez opis uwolnić się od przedstawienia ${ }^{99}$. By jednak ów opis stał się możliwy, rozgrywanie w działaniu musi zostać zastąpione przepracowaniem (working through). Wysiłkiem autoterapeutycznym. Wysłowienie jest w nim walką o dostęp do siebie, o reintegrację podmiotu ${ }^{100}$.

Dlatego narracja większości utworów Romanowiczowej dokonywana jest ex post. Ma służyć wyjaśnieniu własnych i interpretacji cudzych zachowań. Jest próbą zracjonalizowania minionych zdarzeń, opowiedzenia ich w celu intelektualnego ogarnięcia. Jak zaklina narratorka Słońca dziesięciu linii: „to wszystko miało znaczenie, musiało mieć jakieś wspólne, łączące znaczenie"101. W opracowaniach dzieł Romanowiczowej niemal wszyscy badacze podkreślają wywołany wojną, traumatyczny charakter doświadczenia kreowanych przez nią postaci. Jednak trudno wskazać na jedno traumatyczne zdarzenie, które stanęło u podstaw takiej kreacji bohatera. Większość z nich jest jedynie suponowana czytelnikowi. Psychoanalityczna definicja traumy głosi, że jest ona wstrząsającym doświadczeniem tego, co narusza spójność egzystencji, w wyniku czego dochodzi do tymczasowego zerwania więzi z sobą samym. Jak zauważa Amelia Korzeniewska:

Co jednak w procesie tym najciekawsze - to swoisty paradoks związany $\mathrm{z}$ traumą. Stanowi ona bowiem nie tylko tego rodzaju doświadczenie, którego nie da się zapomnieć, lecz także - i na ten aspekt szczególnie chcę zwrócić

${ }^{99}$ Opozycję tę najlepiej obrazują autotematyczne fragmenty Sono felice, w których epicka strategia Szymona nie dociera do zamkniętej Teresy. Podobnie w perspektywie biografii pisarki, jej metoda różni się całkowicie od techniki, której próbował nauczyć ją Melchior Wańkowicz, co skutkuje w jej prozie nieuniknionym powtarzaniem się. W rozmowie ze Stanisławem Beresiem Romanowiczowa przyznaje: „Gdybym słuchała Wańkowicza, musiałabym na wieki zastosować się do jego innego przepisu, który głosił: «Gospodaruj materiałami, nie ładuj wszystkiego do jednego tekstu». Nie posłuchałam tego nigdy, ale dopiero później zorientowałam się, iż pisząc wszystko pakuję do jednej powieści. Wychodzę z założenia, że później będzie, co Bóg da. Nie «gospodaruję»».

${ }^{100}$ A. Zieniewicz, Odmiany paktów autobiograficznych w literaturze XX wieku, [w:] Dwudziestowieczność, M. Dąbrowski, T. Wójcik (red.), Warszawa 2004, s. 266-267.

${ }^{101}$ Słońce dziesięciu linii, s. 22. 
Natalia Królikowska - Zofia Romanowiczowa. Zarys...

uwagę - doświadczenie, o którym się nie pamięta oraz którego nie daje się adekwatnie ująć w słowa ${ }^{102}$.

Podmiot straumatyzowany rozbija więc jedno z podstawowych założeń powieściowego realizmu, czyli jak pisze dalej Zieniewicz: „przekonanie o możliwości wymierzenia sprawiedliwości widzialnemu światu"103. Efekt jest co najmniej dwuznaczny - autorka jest jednocześnie obecna i nieobecna $w$ utworze. $Z$ jednej strony odnajdujemy w utworach Romanowiczowej jej autorską manifestację (przypisując autorce elementy powieściowych światów przedstawionych czy pewne opinie, konkluzje i sądy) z drugiej - pamiętamy o fikcjonalnej konwencji odbioru prozy artystycznej. Wydaje się więc, że zarówno dla Teresy, jak i dla samej pisarki twórczość nie istnieje na zewnątrz tragedii, dlatego nie może jej „po Szymonowemu” opisać. Teresa jest dowodem obecności autora podczas samej katastrofy, milczącej z jej wnętrza ${ }^{104}$. Niemożność komunikacji tematyzuje się z kolei w następnej powieści w dorobku pisarskim Romanowiczowej, stanowiącej punkt kulminacyjny jej twórczości.

Skrytki znacząco różnią się od wcześniejszych powieści Romanowiczowej. Główną bohaterką książki nie jest kobieta, a para - bezimienni mąż i żona, oboje naznaczeni traumą - tym razem jednak nie wojenną - a najbardziej osobistą - chorobą i kalectwem własnego

${ }^{102}$ A. Korzeniewska, Moc obrazów wobec braku słów. Rola mediów w przedstawieniach Holokaustu, [w:] Zagłada. Współczesne problemy rozumienia i przedstawiania, P. Czapliński, E. Domańska (red.), Poznań 2009, s. 233.

${ }^{103}$ A. Zieniewicz, op. cit., s. 267.

${ }^{104} \mathrm{~W}$ mówieniu o holocauście dominuje sformułowanie o niewypowiadalności i unikatowości obozów koncentracyjnych, co prowokuje do pytania o wywyższenie, związane z tajemnicą niemożliwą do opowiedzenia. Bożena Karwowska, analizująca Przejście przez Morze Czerwone zauważyła, iż „w powieści Romanowiczowej dające się opowiedzieć jest prawie wszystko, nawet miłość fizyczna [...]. Opowiedzenie pozwala na uwolnienie się od pamięci, na zmienienie jej w coś zewnętrznego, opowiadalnego. Pozwala na zdemistyfikowanie, odebranie prestiżu związanego z tajemnicą i pozbycie się tęsknoty, związanej z jej zagadkowością" (B. Karwowska, Redefiniowanie kategorii ciała. Doświadczenie nie/stawania się kobieta - świadectwo dojrzewania w obozie koncentracyjnym w „Przejściu przez Morze Czerwone” Zofii Romanowiczowej, [w:] Literackie reprezentacje doświadczenia, W. Bolecki, E. Nawrocka (red.), Warszawa 2007, s. 295). 
dziecka. Odsunięci od wydarzeń historycznych, politycznie niezaangażowani, społecznie przezroczyści, wspólnie doświadczają najintymniejszych trosk egzystencji, trudów codzienności ludzi dotkniętych osobistą tragedią, rzecz absolutnie wyjątkowa w piśmiennictwie polskim początku lat 80. XX wieku. Jak zauważył Włodzimierz Odojewski:

Takich książek w Polsce się nie pisze. Jest nie do pomyślenia, aby krajowy autor nie rzucił spraw indywidualnych, życiowych bohatera na szersze tło społeczne, aby ludzkich nieszczęść nie splótł z nieszczęściami narodu, nie potraktował ich $\mathrm{w}$ kontekście okupacji, masakrującego społeczeństwo walca stalinizmu i owego falowania od nadziei do rozpaczy historii następnych dziesięcioleci. W tej uwadze nie ma pretensji, ani ironii, po prostu stwierdzenie faktu. Bohaterowie krajowej powieści nie mogą iść ze sobą do łóżka nie uzgodniwszy wcześniej swych poglądów na świat 105 .

Inna jest również narracja Skrytek - już nie pierwszoosobowa, sięgająca raz za razem do monologu wewnętrznego czy techniki „strumienia świadomości". Trzecioosobowy narrator nie zajmuje jednak raz na zawsze ustalonej i niezmiennej pozycji. Wręcz przeciwnie - raz za razem dystans narratora zmniejsza się - co widoczne jest szczególnie w tych partiach utworu, w których monolog narratora przechodzi w mowę pozornie zależną, wprowadzającą perspektywę bohaterów. Następuje więc radykalna zmiana punktu widzenia narratora - od boskiego i wszechogarniającego do podmiotowego i indywidualnego.

Po zupełnie wyjątkowych Skrytkach z ich niemal sensacyjną fabułą (o czym pisała Marta Wyka) ${ }^{106}$ Romanowiczowa wraca do swoich ulubionych dociekań natury psychologicznej i etycznej. Następna pozycja w jej dorobku pisarskim, powieść Na wyspie jest - jak zauważa Ewa Nowakowska - „kolejnym rozdziałem wciąż tej samej opowieści, jednorodnej w swojej wielości, rozwijanej i poszerzanej konsekwentnie i prowadzącej w stronę subtelnej, koronkowej analizy psycholo-

${ }^{105}$ W. Odojewski, Czy powieść o ludziach bez narodowości? [w:] „Orzeł Biały” [Londyn] 1981, nr 201.

${ }^{106}$ M. Wyka, Zapomniana sztuka fabuły [w:] „Pismo” 1983, nr 1/2. 
Natalia Królikowska - Zofia Romanowiczowa. Zarys...

gicznej"107. Fabuła jest dość pretekstowa, mało prawdopodobna i wątła. To, co faktycznie „wydarza się” w powieści, zachodzi w psychice cierpiącej na narkolepsję bohaterki, którą ataki choroby raz po raz przenoszą do odległych w czasie i przestrzeni miejsc. Lektura pierwszych rozdziałów $\mathrm{Na}$ wyspie nie przynosi niczego nadzwyczajnego. Rzecz dotyczy spotkania mieszkającej od wielu lat na Wyspie Świętego Ludwika fryzjerki $\mathrm{z}$ tajemniczym obcym mężczyzną. Historia zapowiada się banalnie - jak wiele tuzinkowych romansów. Nieznajomy jest jakby znajomy, przypomina kogoś, ale nie wiadomo kogo. W tych banalnych okolicznościach jest jednak pewna osobliwość, sygnał tajemnicy, której rozwikłanie nastąpi w dalszym ciągu powieści. Jak zwykle u Romanowiczowej - przyroda zapowiada nadciągającą katastrofę:

Rzeka zalała nabrzeże, podeszła pod same schodki, trąca o kamień, liże go, próbuje. Szybko to się dzieje. Zaledwie wczoraj, nie dawniej niż wczoraj o tej samej porze mogła sobie przysiąść na tej oto ławce, o parę kroków stąd i tylko wilgoć, ziąb, mżąca mgła przepędziły ją szybciej niż zwykle[...] ${ }^{108}$.

Ostatnie dwie powieści Romanowiczowej, wydane już w kraju $(R u-$ chome schody w 1995 roku w Państwowym Instytucie Wydawniczym oraz Trybulacje proboszcza P., wydane przez toruńskie wydawnictwo „Algo" w 2001 roku), choć z pewnością nie są dalszym ciągiem historii opowiedzianej w Grobach Napoeleona czy Skrytkach, to powtarzają (a tym samym przewartościowują) te same wątki, motywy, zdarzenia. Potwierdzają to słowa recenzenta, Rafała Moczkodana:

Lektura Trybulacji proboszcza P. dostarcza wielu przyjemności, choć osoby znające jedną z wcześniejszych książek Romanowiczowej - Ruchome schody doznają podczas czytania nieco irytującego literackiego déjà vu. Okazuje się bowiem, że w swej najnowszej powieści pisarka sięgnęła po szereg chwytów znanych z tej wcześniejszej. Przede wszystkim oba utwory zostały oparte na podobnym schemacie: dom - dwie postaci szukające porozumienia - trzecia

${ }^{107}$ E. Nowakowska, W galerii portretu psychologicznego, „Tygodnik Powszechny” 1985, nr 30.

${ }^{108}$ Na wyspie, s. 7. 
postać przywoływana na różne sposoby. Oba domy są zbudowane w dużej części z kamienia. Narratorka Trybulacji szuka porozumienia ze znacznie starszą osobą, narratorka Ruchomych schodów ze znacznie młodszym Tomusiem, obie - przywołują na pamięć ludzi w ich mniemaniu zasługujących na miano wielkich - w Trybulacjach jest to ksiądz P., we wcześniejszej powieści - brat narratorki. W obu książkach obecny jest motyw borykania się z wojennymi wspomnieniami, w obu też w pewnej chwili dochodzi do duchowego zespolenia ludzi należących do różnych pokoleń [...]. Istotną rolę pełnią rękopisy tu kronika Tutejszych i odnalezione przez przypadek Trybulacje, tam listy oraz ukryte w walizce dzieło brata [...] Obie narratorki (jak również Ina) zdradzają wiele podobieństw [...]. Wreszcie $\mathrm{w}$ obu utworach domy będące głównym ośrodkiem zdarzeń «przepadają», co jest związane ze śmiercią ich bohaterek $[\ldots]^{109}$.

Faktycznie, nawet w każdym z tekstów rozpatrywanym oddzielnie, znajdują się powtarzające się ciągle elementy - nie tylko tematyczne czy fabularne, ale także narracyjne - w Trybulacjach proboszcza P. są to historie proboszcza, Iny i narratorki, pobrzmiewające wzajemnym echem. Dodatkowo, wszystkie te opowieści poznajemy z fragmentów, tajemnice losów bohaterów są więc jednocześnie odsłaniane, jak i zakrywane swoją niekompletnością. Narratorka wielokrotnie „zabiera się" do wywiadu z Iną, ale niemal za każdym razem coś staje na przeszkodzie. Opowieść o eksperymentach medycznych w obozach koncentracyjnych przechodzi na dalszy plan, a przedmiotem opisu narratorki stają się codzienne, na pozór trywialne czynności, które jednak poprzez swoją aluzyjność wprowadzają główną historię. Taką funkcję pełni chociażby nauka przycinania róż w ogrodzie Iny. Podobnie jest w Ruchomych schodach, gdzie największy sekret jednego z bohaterów zamknięty jest w tajemniczej walizce, o otwarciu której dowiadujemy się na samym początku powieści, ale której otwarcie jest nieustannie odkładane, aby dokonać się dopiero na samym końcu utworu. Tajemnice, które skrywają bohaterowie Romanowiczowej, separują ich od innych ludzi. Odmowa dzielenia się nimi alienuje i zakłóca komunikację (także tę ze zwodzonym raz za razem czytel-

${ }^{109}$ R. Moczkodan, Literackie déjà vu, „Nowe Książki” 2001, nr 9. 
nikiem) - stąd tak wiele niedopowiedzeń w powieściach Romanowiczowej, miejsc których - tak jak czyjejś tajemnicy - możemy się jedynie domyślać. Jak zauważa Alice Catherine Carls:

Napięcie jest wzmocnione poprzez zastosowanie metody kompozycji znanej jako en abîme, która pozwala artyście odtwarzać scenę główną w mniejszej skali, zwielokrotniając w ten sposób jej początkowy efekt ${ }^{110}$.

Romanowiczowa stosuje tę strategię w sposób innowacyjny i urozmaicony. W innych fragmentach poddaje narrację zabiegowi synkopowania, polegającemu na przerywaniu poetyckich fragmentów i szczegółowych opisów powiedzeniami, zwrotami potocznymi, mentalnymi „skrótami” czy po prostu wykrzyknikami. Ten charakterystyczny dla całego pisarstwa Romanowiczowej styl, w którym realistyczne opisy inkrustowane są niekiedy ironią, a kiedy indziej liryzmem, zdaje się łączyć poszczególnie utwory prozatorskie $\mathrm{w}$ jeden wspólny nurt opowieści-rzeki.

Jeśli przyjmiemy, że gra autobiograficzna jest żywiołem prozy Romanowiczowej, to oczywistą cechą wszystkich jej powieści jest pewna dająca się w nich zauważyć powtarzalność - nie tylko osoby autora, ale także pewnych problemów, wątków, a nawet fabuł. Kategoria powtórzenia, rozumiana nie tylko filozoficznie czy psychologicznie, ale przede wszystkim jako dominanta kompozycyjno-fabularna, pozwala mówić o powieściach Romanowiczowej jako pewnego rodzaju ciągu wariacji na zadany, niegdyś biograficznie, temat. A więc powtórzenie, odnoszące się zarówno do planu fabularnego, jak i do poziomu składniowego (tj. ram kompozycyjnych, zdań-kluczy, czy repetycji składniowych), podporządkowane jest wyrażeniu ludzkiej kondycji, egzystencji toczącej się na kształt błędnego koła, dojmującemu uczuciu melancholii. Ponownie docieramy więc do zagadnień związanych z postaciami bohaterek (a może zasadniej byłoby mówić przy omawianiu tych powieści o jednej i tej samej postaci, a nie o postaciach?) kreowanych przez Romanowiczową, chciałoby się wręcz wskazać je

${ }^{110}$ A. C. Carls, Reżyser, filozof, świadek. Estetyka złamania w utworach Zofii Romanowiczowej, „Archiwum Emigracji”, 2001, z. 4. s. 43. 
jako najistotniejsze zagadnienie poetyki tego pisarstwa. Mamy tu bowiem do czynienia z wyjątkową konstrukcją bohaterek - bohaterek negatywnych nie $\mathrm{w}$ sensie etycznym, a ontologicznym - biernych, amorficznych, nieokreślonych, cierpiących, masochistycznych, absurdalnych w swoim bytowaniu, specyficznie rozerotyzowanych.

Zofia Romanowiczowa dała światu rzadki przykład dezercji, ucieczki od istnienia. Brak jej pisarstwa w kanonie wydaje się nie być jedynie skutkiem procesów historycznoliterackich (takich jak np. powrót pisarzy emigracyjnych do kraju po 1989 roku) ${ }^{111}$ czy recepcji (wszak jak wykazałam, ta była jak najlepsza!) ${ }^{112}$, ale postawy samej

${ }^{111}$ Interesujące są uwagi redaktora naczelnego czasopisma „Odra”, Mieczysława Orskiego, ubolewającego nad nieobecnością Romanowiczowej we współczesnym kanonie literackim. We wstępie do artykułu, którego pretekstem było ukazanie się na polskim rynku wydawniczym ostatniej powieści pisarki, Trybulacji Proboszcza P., autor pisze: „Siedem lat temu, pisząc o jednej z wydanych w kraju powieści Zofii Romanowiczowej, zadawałem sobie trud przybliżenia postaci świetnej, a wciq̨ż u nas niedocenianej pisarki emigracyjnej; od tego czasu zmieniło się tyle, że autorka najnowszych wydanych ostatnio «Trybulacji Proboszcza P.» (ALGO, Archiwum Emigracji, Toruń 2001) nadal pozostaje w gronie «niedocenianych» (mimo przyznanej w tym roku Nagrody Ministra Kultury i Dziedzictwa Narodowego, która nie poskutkowała wysypem na rynek księgarski jej książek), choć już zapewne nie «emigracyjnych» pisarzy. Tak się bowiem - może trochę niepostrzeżenie, lecz chyba naturalnie stało, że emigracja literacka zasymilowała się z piśmiennictwem krajowym, co zawdzięczamy fundamentalnym zmianom politycznym, i faktom obiektywnym, takim że np. Miłosz pół roku żyje w Krakowie, a kiedy robi się zimniej, wyjeżdża na następne pół roku do swojej Kaliforni [...]. Książek Romanowiczowej trudno dziś uświadczyć nawet w bibliotekach, a przecież napisała i wydała ich sporo - i sądzę, że wiele spośród nich stanowiłoby godną konkurencję na coraz skromniejszych półkach z beletrystyką współczesną w naszych księgarniach; rynek wznowień w Polsce regulują dziś głównie układy towarzysko-środowiskowe, a autorka «Trybulacji Proboszcza P.» mimo swych olbrzymich zasług dla sprawy polskiej w czasach reżimu [...] nie dostąpiła szansy «awansu» ani do towarzystwa wzajemnej samopomocy wydawniczej, ani do odpowiednio skutecznego środowiska literackiego” (idem, Romanowiczowa, „Arkusz" 2002, nr 1).

${ }^{112}$ Marian Hemar, zaraz po ukazaniu się zbioru opowiadań Próby i zamiary pisał, że jest to książka „z rzędu tych, których autorzy dostają Nagrodę Nobla” (Nowa laureatka, „Tydzień Polski” 1966, nr 14). Z kolei Jan Bielatowicz, jeden z większych admiratorów twórczości Romanowiczowej, we wstępie recenzji powieści Słońce Dziesięciu linii twierdził, iż „Zofia Romanowiczowa stanęła w rzędzie pierwszych i znanych w świecie pisarek polskich dzięki powieści Przejście przez Morze Czerwone, wydanej na emigracji i przedrukowanej w Kraju, przełożonej na języki francuski, niemiecki, 
Natalia Królikowska - Zofia Romanowiczowa. Zarys...

autorki, która nie zabiegała o atencję czytelników, krytyków i wydawców, a także wielokrotnie deprecjonowała swoją twórczość. Nieobecność wiąże się wszak z nie-znaczeniem, jeśli założymy, że obecność ciąży ku znaczeniu i nie kończy się na samym utworze, pojmowanym jako zamknięte i ukończone dzieło, ale przemieszcza się w stronę szerszej komunikacji literackiej, do której zarówno osoba autora, jak i czytelnika wydaje się konieczną ${ }^{113}$. W jednym ze swoich artykułów Romanowiczowa porównała pisanie do budowania domu:

\begin{abstract}
Skrytki pełne są najrozmaitszych, własnych i cudzych skrytek. Sądząc po reakcjach na nie, wydaje mi się czasem, że zmieściłam w nich nie jedną, a parę zupełnie rozmaitych książek. W każdej z nich tkwiłam, otwierały się przede mną w momentach twórczej łaski, zatrzaskiwały się na długie okresy zwątpienia. Dziś nie potrafiłabym już ani ich zacząć, ani skończyć. To tak jak z domem, który się zbudowało. Przestaje należeć do architekta, choć nadal nosi jego nazwisko. Należy do tych, co w nim zechcą zamieszkać, do tych, co go własnym kluczem otworzą ${ }^{114}$.
\end{abstract}

holenderski i angielski” (idem, Słońce dziesięciu linii, „Na antenie” 1963, nr 6). Bielatowicz wyrażał pochwały pod adresem pisarki już dużo wcześniej, tuż po ukazaniu się Baśki i Barbary. W 1957 roku w londyńskich „Wiadomościach” pisał o Romanowiczowej jako największej nadziei polskiego piśmiennictwa na obczyźnie w pokoleniu, które zaczęło tworzyć po wojnie. Por. idem. Zofia Romanowiczowa, „Wiadomości” 1957, nr 35. [treść tego przypisu dałabym do tekstu głównego]

${ }^{113} \mathrm{O}$ tym, jak ważna dla Zofii Romanowiczowej była komunikacja, świadczą jej wspomnienia o próbach poetyckich z czasów, kiedy więziona była przez niemieckich okupantów w zakładach karnych czy obozach. W jednym z wywiadów na pytanie dziennikarza, Henryka Horosza, o to, jakie jest dla niej najważniejsze wspomnienia związane z twórczością, pisarka odpowiada: „Wojna była tuż i zarazem więzienie i obóz w Ravensbrück. To punkt kulminacyjny w mojej twórczości poetyckiej, której potem zaniechałam. Wiersze tam powstałe były słabe literacko, nawet całkiem marne, gdy je sądzić na chłodno. Ale w lagrowe niedziele, gdy je mówiłam głośno na szczelnie zapełnionym «trzeciaku», wiedziałam, że mówię nie tylko dla wielu, a zamiast wielu, że wyrażam uczucia zbiorowe. Takiej atmosfery uniesienia, zespolenia się nie sposób odtworzyć i wszelkie późniejsze satysfakcje czy nawet sukcesy są niczym” (idem, Francja na co dzień. Wywiady i wizyty, „Panorama Północy”, Olsztyn 1965, nr 47). Przekonanie o wspólnotowym charakterze pisarstwa, o budowaniu wokół utworu pewnej szczególnej międzyludzkiej więzi, swoje odbicie znalazło niewątpliwie w pracy zawodowej Zofii Romanowiczowej, czyli w prowadzeniu wydawnictwa oraz galerii, w których spotykała się polska, i nie tylko polska, elita ówczesnego Paryża.

${ }^{114}$ Zofia Romanowiczowa o sobie, „Kultura” [Paryż] 1981, nr 12. 
Wycofanej Romanowiczowej, próbującej zamknąć swoje doświadczenie w formie powieściowej - jednocześnie ją przekraczając - szukać należy więc $\mathrm{w}$ jej tekstach, w tych miejscach niedookreślonych, niedopowiedzianych, opierających się pełnej artykulacji. Czytając powieści Romanowiczowej, ma się wrażenie, że w dużym stopniu modeluje je obawa przed pełną i otwartą autoprezentacją pisarki. Lęk przed niewypowiedzeniem towarzyszy również niektórym z jej bohaterek, a źródeł owego lęku doszukać można się już w młodzieńczych, obozowych poezjach Romanowiczowej115. Używając kryteriów proto-tekstualnych, wzorów literackości, którymi posługiwała się autorka Przejścia przez Morze Czerwone, wskazać możemy tematy i problemy mniej lub bardziej eksponowane, spisane i przemilczane anegdoty. Myślę, że jest to częściowo związane ze środowiskiem, w którym przyszło tworzyć pisarce z Radomia. Paryska emigracja była z jednej strony skostniała, tradycyjna, i bardzo wymagająca, z drugiej wesoła i prześmiewcza. Symbolem pierwszej jest nobliwy i wymagający Jerzy Giedroyć, symbolem drugiej - dusza towarzystwa Konstanty Kot Jeleński116. Pytanie więc dotykające nie tylko Romanowiczowej, rozdar-

${ }^{115}$ Weźmy na przykład przytoczony przez Jana Bielatowicza, w jednym z jego wielu artykułów poświęconych pisarce, wiersz, w którym podmiot liryczny mówi o swoim lęku przed tym, że nie zdąży, bądź nie będzie potrafił wypowiedzieć swojego doświadczenia. Pomimo, że w niniejszej pracy nie zajmuję się poezją Romanowiczowej, uważam, że fragment ten wart jest przytoczenia jako pewien kontekst dla twórczości prozatorskiej pisarki z Wyspy Świętego Ludwika:

„Najbardziej jest mi szkoda nie lat mych dziewczęcych,

Nie matki, ani ciebie, nie świata, nie wiosen,

Lecz pieśni, która we mnie niecierpliwie dźwięczy

I czeka, aż ją w górę, jak żagiew podniosę,

I najciężej mi będzie umrzeć z myślą ową,

Że ból, co ciałem moim śmiertelnie zatarga,

Zabije razem ze mną utajone słowo,

Zanim mi, niby płomień, zakwitnie na wargach"

(idem, Zofia Romanowiczowa, „Wiadomości”1957, nr 35).

${ }^{116}$ Tak o Jeleńskim mówiła sama Romanowiczowa: „Był czarujący, o dużym poczuciu humoru. Wszystko brał, to nie to, że nie na poważnie, ale $\mathrm{w}$ takim świetle wyzwalającego humoru. Był niesłychanie uczynny, jak to się mówi po francusku, był niesłychanie «disponsible». Dla nas, ale nie tylko dla nas, był bardzo wiernym i dobrym przyjacielem. Zdawaliśmy sobie wszyscy sprawę $w$ jak rozmaitych dziedzinach 
tej pomiędzy pragnieniem uzewnętrznienia na swój sposób własnego, indywidualnego doświadczenia, a uległością wobec poetyki i społecznych obrządków emigracji dotyczy właśnie tego, co odsłaniać ma proponowana przez pisarkę literackość jej powieści? Powszechnie wiadomo, że presja owych obrządków była na tyle znaczna, że Romanowiczowa, podobnie jak wielu innych, respektowała je z lęku nie tylko o swój prywatny, ale także publiczny wizerunek (wszak była żoną Kazimierza Romanowicza, ważnej postaci paryskiej emigracji). Całe piśmiennictwo Romanowiczowej (nie tylko powieści, ale również publikowane $\mathrm{w}$ prasie emigracyjnej wspomnienia i artykuły) charakteryzuje taka pełna obaw i zawstydzenia postawa - co odbija się nie tyle w biograficznych, co stylistycznych perypetiach autorki Grobów Napoeleona. 0 tym, jak pisać, jak notować do krajobrazów i dawać świadectwo, uczy Teresę Szymon z Sono felice, stawiając jej wysokie wymagania w dziedzinie chociażby języka literackiego, którym Teresa musi sprostać, by móc w ogóle identyfikować siebie jako pisarkę ${ }^{117}$.

Umieszczając swoje bohaterki bliżej czy dalej od Zagłady, Romanowiczowa nie może uwolnić się z piekła, bo jak mówi Ina z Trybulacji proboszcza P.: „nie da się wyjść z obozu”118. Przyjęta przez pisarkę strategia „trudnych zwierzeń”, czyli opowiadania z głębokiej, wewnętrznej defensywy, jest próbą ucieczki od nieuchronnej stereotypizacji przeciwko rzeczywistym bądź domyślnym głosom krytycznym.

\footnotetext{
Kot pomagał, wprowadzał, doradzał, ułatwiał, wykorzystując wszystkie swoje możliwości” (Rozmowa z Zofiq Romanowiczowq, „Obecność”, nr 21).

${ }^{117} \mathrm{O}$ tym, jak głęboko znajomość Teresy z Szymonem zaczerpnięta jest z biografią Romanowiczowej świadczy ogromne podobieństwo jej opisu z opowiadaniem pisarki o jej przyjaźni z Melchiorem Wańkowiczem, w cytowanym już wywiadzie udzielonym Stanisławowi Beresiowi: „Wańkowicz przejrzał moje wiersze i powiedział: «Ty pisz takie rzeczy, o których my tu jeszcze nic nie wiemy. Powinnaś to wszystko opisać prozą». Wie pan przecież, że w tamtych czasach o obozach nie wiedziało się prawie nic. I dał mi maszynę do pisania! Uczył mnie wszystkiego od zera: akapitów, interlinii. Ciągle kreślił: «To nie tak! Musi być żywiej»! Nauczył mnie techniki pisania prozą. Korektę mojego pierwszego opowiadania «Tomuś» on właśnie wykonał. Jak by to było wypracowanie szkolne! No i tak się zaczęło” (St. Bereś, Fałdy czasu, „Odra” 1990 nr 1, s. 16).

${ }^{118}$ Trybulacje Proboszcza P., s. 97.
} 
Autobiografizm Romanowiczowej możemy nazwać, za Edwardem Balcerzanem, „dzisiejszym”, czyli takim, który nie rezygnuje w sposób mechaniczny z fikcji na rzecz dokumentu, w zamian - tworzy między nimi coraz to nowe napięcia ${ }^{119}$. Czasami jest to umotywowane pewną autorską intencją, innym razem predyspozycjami warsztatowymi pisarza. I tak na przykład - Romanowiczowa nie czuła się dobrze w kreowaniu teł, dlatego jak sama przyznaje „tła zawsze są u mnie autentyczne" 120 . Autobiografia ciąży więc w powieści do autoprezentacji121, czyli zdyskursyfikowanej opowieści o figurze pewnego symbolopodobnego, aczkolwiek modalnego i zmiennego, różnoimiennego „ja”. W opinii Ewy Nowakowskiej żadna z powieści autorki Skrytek nie jest autobiografią $w$ sensie, $w$ jakim definiuje ją Lejeune ${ }^{122}$, co nie przeszkadza badaczce wykorzystywać definicji i rozróżnień zaproponowanych przez autora koncepcji paktu autobiograficznego. W przypadku pisarstwa Romanowiczowej mówić możemy co najwyżej o «powieści autobiograficznej», a ściślej tylko o jej elementach, jako że podobieństwa lub powtórzenia, które skłaniają do postulowania tożsamości autorki i jej bohaterek - zresztą przy braku potwier-

${ }^{119}$ E. Balcerzan, Przygody człowieka ksiq̨żkowego (ogólne i szczególne), Warszawa 1990, s. 30.

${ }^{120}$ Fałdy czasu. Z Zofia Romanowiczowa rozmawia Stanisław Bereś, „Odra” 1990, nr 1.

${ }^{121}$ Za głównego teoretyka autoprezentacji uważa się Ervinga Goffmana, który w swojej najsłynniejszej rozprawie Człowiek $w$ teatrze życia codziennego, zdefiniował występ (performance) jako rodzaj bezpośredniej interakcji w trakcie której jednostka prezentuje swoją tożsamość w taki sposób, aby kontrolować wywieranie wrażenia na innych (zob. E. Goffmann, Człowiek w teatrze życia codziennego, oprac. i wstęp J. Szacki, Warszawa 1981). Punktem wyjścia tej teorii jest przekonanie badacza o tym, że kiedy jednostka znajduje się w obecności drugiego człowieka, modeluje swoje zachowanie w taki sposób, aby wejść w odpowiednią do danej sytuacji - rolę. Jednostka zostaje więc w pewnym sensie rozbita na dwie osoby - na wykreowaną postać oraz na reżysera tej kreacji, co znajduje oparcie w psychologicznym odróżnieniu „ja przedmiotowego" i „ja intencjonalnego", czyli w tzw. dynamicznej koncepcji selfu. Por. K. Obuchowski, Człowiek intencjonalny, Warszawa 1993; P. Oleś, Dynamiczny self: implikacje dla zjawiska autodestrukcji [w:] Wybrane zagadnienia z psychologii osobowości, pod red. idem, Lublin 1997.

${ }^{122}$ P. Lejeune, Pakt autobiograficzny, „Teksty” 1975, nr 5. 
Natalia Królikowska - Zofia Romanowiczowa. Zarys...

dzenia tej tożsamości przez autorkę - dotyczą jedynie pewnych fragmentów powieści. W tej sytuacji znacznie bardziej adekwatne wydaje się pojęcie "przestrzeni autobiograficznej» (znowu zgodnie z poglądami Lejeune’a), która odsyła do autora i w której weryfikować się mogą zawarte w utworze prawdy ${ }^{123}$. Skonstruowany w ten sposób akt opowiadania przenosi uwagę czytelnika $\mathrm{z}$ poziomu opisu świata przedstawionego na samego sprawcę tekstu, czyniąc pozornie realistyczny opis zdarzenia autoprezentacją podmiotu. Zieniewicz rozważa takie działanie na dwa sposoby:

Albo, wedle wczorajszej konwencji odbioru fikcji realistycznej, „wyłączyć” autora rzeczywistego, uznając, że celowo kreuje tak właśnie mówiącego narratora, albo go „uobecnić”, założywszy że to on sam ujawnia się, odsłania, zdradza, choćby jako użytkownik repertuaru frazeologicznego - w wyborach określeń „z innej realności” [...] ${ }^{124}$.

Drugie, wyszczególnione przez badacza, „anakolutyczne” ujęcie pyta, w jaki sposób autor jest obecny w swojej opowieści, czy potrafi się za nią ukryć, czy wręcz przeciwnie - dużo ona o nim mówi. Z tej perspektywy opowieść o Halinie ze Szklanej kuli jest nie tylko powołaniem fikcyjnego opowiadacza, lecz wykreowaniem przestrzeni niejednoznacznej narracyjnie, w której zwracający się do czytelnika głos musi zostać odniesiony potrójnie - zarówno do bohaterki, jak i do narratorki, jak również do autorki-Romanowiczowej jako dawczyni opowieści. Mimo tego nie można ściśle wiązać autora rzeczywistego z kolejnymi instancjami mówiącymi z wnętrza tekstów. Kategoria „utożsamienia” jest w kontekście prozy Romanowiczowej nieprawomocna, anachroniczna i niewystarczalna dla oddania zależności pisarza i wykreowanych przez niego podmiotów ${ }^{125}$. Bohaterki oraz narra-

${ }^{123}$ E. R. Nowakowska, O geście kreacyjnym w twórczości Zofii Romanowiczowej, „Ruch Literacki”, 1989, z. 6.

${ }^{124}$ A. Zieniewicz, op. cit., s. 43.

${ }^{125}$ Przed pułapką „utożsamiania” przestrzegała sama Romanowiczowa, dostrzegając $\mathrm{w}$ analizach swojej twórczości, tendencję do zbytniego psychologizowania: „Wszyscy krytycy okropnie psychologizują. Kiedy czytam ich teksty, widzę, że wycho- 
torki Romanowiczowej wyrażają więc Rimbaudowskie „ja to ktoś inny", będąc fikcjonalną (aczkolwiek werystyczną) wersją tożsamości możliwych autorki, wytwarzanych na kanwie nadinterpretowanych jednych i niedointerpretowanych innych faktów o sobie. Za pierwsze zaryzykowałabym uznanie doświadczenia wojny i emigracji, za drugie - relacji seksualnych i związków emocjonalnych. W różnych powieściach wątki te zajmują różne pozycje w porządku istnienia bohaterek - raz uwypuklane są np. kwestie ciała i płciowości (jak w Przejściu przez Morze Czerwone), żeby gdzie indziej zejść na plan dalszy (np. w Szklanej Kuli). Dlatego konieczne wydaje się ponawianie przez interpretatorów owych reżyserskich zabiegów, w sytuacjach kiedy dzieło wymaga, już nie od autora, lecz od czytelnika, takiej autokorekty. Sam autor, wciągnięty w układ interpretacyjny umożliwiający opisanie jednolitości poetyki czy stylistyki staje się wówczas admonicją, czyli kulturową atrybucją dzieła126. Recenzujący Słońce dziesięciu linii Jan Bielatowicz potwierdza moje przypuszczenia:

Bohaterem „nowej powieści” jest pierwsza osoba, osoba narratora, z czego bynajmniej nie wynika, że musi to być osoba tożsama $\mathrm{z}$ autorem. Tak też w Słońcu dziesięciu linii pierwsza osoba powieści wyposażona jest w rysy fizyczne i duchowe oraz ustawiona w takich sytuacjach, że czytelnik nie może wątpić iż «ja» autorki jest tutaj tylko wcieleniem fikcyjnym ${ }^{127}$.

W przypadku paktu traumatycznego przedstawienie jest uwikłane w autobiograficzny zwrot do przeszłości jako źródła wszelkiego doświadczenia i przeżycia ogniskującego. Podmiot straumatyzowany rozdarty jest więc pomiędzy melancholijnym tu, a nieosiągalnym i „nieopowiadalnym” tam. A ujawnienie autora staje się dramatycznym umiejscowieniem się po stronie tych, którzy przeżyli. Siłą rzeczy pisarz staje się ważnym znakiem w kulturze, a jego biografia ewokuje

dzę na wszetecznicę, która ma tak zwane ukryte życie. Psychoanalizują bez przerwy. Szalenie mnie to bawi” (St. Bereś, Fałdy czasu, „Odra” 1990 nr 1, s. 12).

${ }^{126} \mathrm{~W}$ ten sposób kategorię autora rozpatruje m.in. Michael Foucault. Por. idem, Kim jest autor [w:] Powiedziane, napisane. Szaleństwo i literatura, Warszawa 1999.

${ }^{127}$ J. Bielatowicz, Słońce dziesięciu linii, „Na antenie”, Monachium 1963, nr 2. 
Natalia Królikowska - Zofia Romanowiczowa. Zarys...

pewną mitologię, twórczość natomiast ma funkcję nie tylko dokumentalistyczną, ale przede wszystkim etopojetyczną, tzn. umożliwiającą zamianę prawdy w etos.

Takie przekształcenie ma charakter podwójny - pisze Zieniewicz - ukazuje moment biogramu jako niewyrażalny poza autentykiem, ale służy także terapeutycznemu, hermeneutycznemu odnowieniu relacji ze sobą. Wobec literackości tak rozumiana biografia jest hipoteką. Pozwala pisarzowi otwierać rachunki, których nie można spłacić zmyśleniem ${ }^{128}$.

Za przykład niech posłuży tematyka dzisiejszych wyborów moralnych w kontekście obozowych doświadczeń w Baśce i Barbarze czy samotności z wyboru bohaterki Na wyspie - to nie jest problematyka, którą można rozpatrywać tylko dokumentalnie bądź tylko fikcjonalnie. Podmiot - zdaniem Jean'a Starobinskiego:

(...) nie będzie opowiadać tylko, co mu się zdarzyło w innym czasie, lecz przede wszystkim - w jaki sposób będąc innym, stał się sobą [...].. Łańcuch przeżytych epizodów wytycza drogę (niekiedy krętą), która prowadzi do aktualnego stanu podsumowującego poznania ${ }^{129}$.

Opowieść rozumiana w ten sposób dąży do odpowiedzi na pytania: „Kim jest? Kim się stał?” podmiot wypowiedzi w kontekście przeżytych zdarzeń organizujących teraźniejsze "ja” narratora czy bohatera. Ujawnienie przeżycia ogniskującego jest możliwe tylko w takiej - nie będącej formułą, lecz reinterpretacją, powtórnym zrozumieniem opowieści, zbudowanej nie według wcześniejszego życiowego i doznawanego scenariusza, lecz na kanwie rozjaśnionego, zrozumianego niegdyś głębinowego doświadczenia. Tekst powieści staje się więc pewną strategią autobiograficzną, porządkiem zsemiotyzowanym, pisanym z perspektywy życia ex post, na wzór utajonego logosu biogramu. W niektórych powieściach Romanowiczowej w gruncie rzeczy ten sam podmiot (jeśli za takiego przyjąć straumatyzowanego ocaleńca) zostaje rozszczepiony na dwie postaci - narratora, posiadającego wiedzę pełniejszą oraz na nieświadomego bohatera. Tak jest np.

\footnotetext{
${ }^{128}$ A. Zieniewicz, op. cit., s. 62.

${ }^{129}$ J. Starobinski, Styl autobiografii, „Pamiętnik Literacki” 1979, z. 1.
} 
w Łagodnym oku błękitu, gdzie główną bohaterką jest naiwna i zamknięta w sobie Misia, która - jak mówi o niej w jednym z wywiadów Romanowiczowa - „nie dożyła do przeżycia”130 i której losy poznajemy z perspektywy tej, która ocalała, czyli panny Dominiki ${ }^{131}$. Zrozumienie i refleksja nad tym, czego doświadczyło się w obozie, możliwa jest tylko z pewnego oddalenia, bo jak mówi sama Romanowiczowa: „Aby przeżyć obóz fizycznie i psychicznie, nie można było dopuścić do siebie wszystkiego. To zamknięcie w sobie było swoistym pancerzem ochronnym"132.

Powieści Zofii Romanowiczowej nie dają się pomyśleć jako utwory bezautorskie, wręcz przeciwnie - raz po raz dopominają się one o swoją autorkę ${ }^{133}$. Całkowite wycofanie pisarki nie jest więc do końca możliwe, a jej nieobecność nieostateczna. W tekście pozostaje bowiem jej lepiej lub gorzej ukryty ślad - czy to w postaci bohatera autorskiego, czy wnikliwie analizowanego przez Annę Jamrozek-Sowę sobowtóra. W zdyskursyfikowanych wypowiedziach pozaliterackich (wywiadach, wspomnieniach, artykułach) nie ma tej podwójności, przez co są one uboższe o swój głębszy sens, bo właśnie ze zderzenia tych głosów powieść czerpie energię uruchamiającą nowe, ciekawe znaczenia. Oczekiwanie w lęku, tak mistrzowsko pokazane w Przejściu przez Morze Czerwone jest typowe dla całego pisarstwa Romanowiczowej. Cała jej późniejsza twórczość jest pochodną doświadczenia zawieszenia w oczekiwaniu na ostateczne rozstrzygnięcie.

Twórczość Zofii Romanowiczowej z pewnością zasługuje na to, aby zostać na nowo zbadana. Mimo że jest to po trosze wiadome, to jednocześnie jest to po trosze zaniechane. Jak pokazałam, powodów do

${ }^{130}$ St. Bereś, Fałdy czasu, „Odra” 1990 nr 2, s. 20.

${ }^{131} \mathrm{~W}$ tej podwójności manifestuje się jeden z największych problemów literatury powojennej, tzw. „paradoks świadka”, sformułowany przez Primo Leviego. Por. idem, Pograżeni i ocaleni, Kraków 2007.

${ }^{132}$ St. Bereś, Fałdy czasu, „Odra” 1990 nr 2, s. 21.

${ }^{133}$ Mam tu na myśli funkcję autora, rozumianą przez Michaela Foucaulta jako instancję, do której tekst odsyła w trakcie lektury. Por. idem, Kim jest autor [w:] Idem, Powiedziane, napisane. Szaleństwo i literatura, Warszawa 1999, s. 201. 
Natalia Królikowska - Zofia Romanowiczowa. Zarys...

przemyśleń, jak i do przemilczeń nie brakuje. Jak podsumowuje Jan Bielatowicz: „nie ma ucieczki od istnienia. Nie ma ucieczki od istnienia w narodzie i dla narodu, jeżeli twórczość ma być szczera i pełna"134.

\section{Bibliografia:}

Wszystkie cytaty z tekstów autorstwa Zofii Romanowiczowej zostały podane w pracy według wydań:

- Baśka i Barbara (powieść), wyd. Libella, Paryż 1956; Państwowy Instytut Wydawniczy, Warszawa 1958 (wydanie II i III); wyd. Libella, Paryż 1985 (wydanie fotooffsetowe).

- Groby Napoleona (powieść), wyd. Polska Fundacja Kulturalna, Londyn 1972.

- Lagodne oko błękitu (powieść), wyd. Libella, Paryż 1968; wyd. PAX, Warszawa 1987.

- Na wyspie (powieść); wyd. Instytut Literacki, Paryż 1984.

- Próby i zamiary (opowiadania), wyd. Polska Fundacja Kulturalna, Londyn 1965.

- Przejście przez Morze Czerwone (powieść), wyd. Libella, Paryż 1960, Państwowy Instytut Wydawniczy, Warszawa 1961.

- Ruchome schody (powieść), Państwowy Instytut Wydawniczy, Warszawa 1995.

- Skrytki (powieść), wyd. Instytut Literacki Paryż 1980.

- Słońce dziesięciu linii (powieść), wyd. Libella, Paryż 1963.

- Sono felice (powieść), wyd. Polska Fundacja Kulturalna, Londyn 1977; wyd. Siedmioróg, Wrocław 1995.

- Szklana kula (powieść), wyd. Libella, Paryż 1964.

- Trybulacje proboszcza P. (powieść), wyd. Algo, Toruń 2001.

\section{Pozostałe źródła:}

Araszkiewicz A., Wypowiadam wam moje życie: melancholia Zuzanny Ginczanki, Warszawa 2001.

${ }^{134}$ J. Bielatowicz, Zosia i Zofia, „Wiadomości” 1964, nr 45. 
Balcerzan E., Przygody człowieka ksiq̨żkowego (ogólne i szczególne), Warszawa 1990.

Bereś St., Fałdy czasu, „Odra” 1990 nr 1.

Bereś St., Fałdy czasu, „Odra” 1990 nr 2.

Bereza H., W hołdzie marzeniom, „Twórczość” 1961, nr 8.

Bielatowicz J., Słońce dziesięciu linii, „Na antenie”, Monachium 1963, nr 2.

Bielatowicz J., Zosia i Zofia, „Wiadomości” 1964, nr 45.

Bielicki M., Dwie ksiqż̇ki pisane „stamtąd”, „Żołnierz Wolności” 1958, nr 73.

Bogusławski A., Mądrze i ładnie, „Dziennik Polski” 1956, nr 157.

Bolecki W., Czym stała się dziś historia literatury [w:] Wiedza o literaturze i edukacja Księga referatów Zjazdu Polonistów, T. Michałowska, Z. Goliński, Z. Jarosiński (red.), Warszawa 1996,

Brach-Czaina J., Szczeliny istnienia, Kraków 1999.

Bujnowski J., Niektóre uwagi o piśmiennictwie Zofii Romanowiczowej, „Pamiętnik Literacki” 1989, z. 14.

Burzacka I., Macierzyństwo jako temat literacki. O „Baśce i Barbarze” Zofii Romanowiczowej [w:] Modernizm. Zapowiedzi, krystalizacje, kontynuacje, A. Grzelak, M. Kurkiewicz (red.), Bydgoszcz 2009.

Carls A. C., Reżyser, filozof, świadek. Estetyka złamania w utworach Zofii Romanowiczowej, „Archiwum Emigracji”, 2001, z.4.

Czapska M., Do samego dna doznań, „Tydzień Polski” 1961, nr 13.

Danilewicz-Zielińska M., Szkice o literaturze emigracyjnej, Wrocław 1992.

Detka J., Zofia Romanowiczowa [w:] Pisarze regionu świętokrzyskiego, J. Pacławski (red.), Kielce 1997.

Escrapit R., Literatura a społeczeństwo [w:] W kręgu socjologii literatury. Antologia tekstów zagranicznych, wstęp i oprac. A. Mencwel, Warszawa 1977, t. 1.

Filipiak I., Obszary odmienności: rzecz o Marii Komornickiej, Gdańsk 2006.

Głowiński M. M., Konstrukcja a recepcja. Wokół „Dziejów grzechu” Żeromskiego [w:] Idem, Gry powieściowe, Warszawa 1973.

Gralewicz-Wolny I., Skrytki w sercach. O jednej powieści Zofii Romanowiczowej, [w:] Rodzina w czasach przełomów. Literackie diagnozy od XIX do XXI wieku, K. Kralkowska-Gątkowska (red.), Katowice 2011.

Iwasiów I., Gender dla średnio zaawansowanych. Wykłady szczecińskie, Warszawa 2004. 
Natalia Królikowska - Zofia Romanowiczowa. Zarys...

Janion M., Czytać jeszcze raz, [w:] tejże, Odnawianie znaczeń, Kraków 1980, s 24.

Jazówna S., O „Łagodnym oku błękitu” Zofii Romanowiczowej, „Kronika” 1968, nr 49-50.

Kłosińska K., Ciało, pożądanie, ubranie: o wczesnych powieściach Gabrieli Zapolskiej, Kraków 1999.

Korzeniewska A., Moc obrazów wobec braku słów. Rola mediów w przedstawieniach Holokaustu, [w:] Zagłada. Współczesne problemy rozumienia i przedstawiania, P. Czapliński, E. Domańska (red.), Poznań 2009, s. 233.

Kossak J., Wstęp [w:] A. Camus, Eseje, Warszawa 1971.

Kozarynowa Z., Udział Polaków w literaturach zachodnich [w:] Literatura polska na obczyźnie 1940-1960, T. Terlecki (red.), Londyn 1965.

Lang B., Przedstawianie zła: etyczna treść a literacka forma [w:] Idem, Nazistowskie ludobójstwo. Akt i idea, Lublin 2006.

Lejeune P., Pakt autobiograficzny, „Teksty” 1975, nr 5.

Lisiecka A., Pokolenie „pryszczatych”, Warszawa 1964.

Łebkowska A., Dotyk - piętno - ciało. O jednej powieści Zofii Romanowiczowej, [w:] Od polityki do poetyki. Prace ofiarowane Stanisławowi Jaworskiemu, C. Zalewski (red.), Kraków 2010

Maciąg W., Nowości prozy, „Życie Literackie” 1965, nr 9.

Mamoń B., Strach przed drugim brzegiem, „Tygodnik Powszechny” 1961, nr 31.

Mazurek D., Kobieta i wojna. O twórczości Zofii Romanowiczowej, [w:] Kobieta w literaturze i kulturze, D. Mazurek (red.), Lublin 2004.

Moczkodan R., Literackie déjà vu, „Nowe Książki” 2001, nr 9.

Nowakowska E., Eksperymenty Zofii Romanowiczowej, „Tygodnik Powszechny" 1988, nr 24.

Nowakowska E., W galerii portretu psychologicznego, „Tygodnik Powszechny" 1985, nr 30.

Nowakowska E. R., O geście kreacyjnym w twórczości Zofii Romanowiczowej, „Ruch Literacki”, 1989, z. 6.

Nowakowski T., Przejście przez morze biało-czerwone, „Wiadomości” [Londyn] 1966, nr 26.

Odojewski W., Czy powieść o ludziach bez narodowości? [w:] „Orzeł Biały” [Londyn] 1981, nr 201.

Olszewski W., Szklana kula, „Horyzonty” 1965, nr 104. 
Olszewski W., Zofia Romanowiczowa. Łagodne oko błękitu, „Horyzonty” 1968, nr 142.

Orski M., W pogoni za szczęściem. Zofia Romanowiczowa „Sono felice”, „Przegląd Powszechny" 1997, nr 1.

Pippett A., Faithless Lucile, „New York Times Book Review” 1962, nr 15.

Poradecki J., Pisarstwo Wilhelma Macha, Łódź 1984.

Ritz G., Nić w labiryncie pożądania. Gender i płeć w literaturze polskiej od romantyzmu do postmodernizmu, Warszawa 2002.

Romiszewski E., Groby Napoleona. Nowa powieść Zofii Romanowiczowej, „Na antenie" [Londyn] 1973, nr 121.

Sakowski J., Rok 1966. „Próby i zamiary” Romanowiczowej, „Wojna i sezon” Pawlikowskiego [w:] Idem, Dawne i nowe lata, Paryż 1970.

Starobinski J., Styl autobiografii, „Pamiętnik Literacki” 1979, z. 1.

Szacki J., O kanonie kultury europejskiej uwagi sceptyczne, „Znak” 1994, nr 7.

Szaruga L., Kanon jako przestrzeń porozumienia [w:] Kanon i obrzeża, I. Iwasiów, T. Czerska (red.), Kraków 2005.

Szpociński A., Kanon kulturowy, „Kultura i Społeczeństwo” 1991, nr 2.

Walas T., Czy jest możliwa inna historia literatury?, Kraków 2003.

Wańkowicz M. M., List do Zofii Romanowiczowej z 25 I 1974 [w:] A. A. Ziółkowska, Na tropach Wańkowicza, Warszawa 1989, s. 59.

Wittlin J., Młoda proza emigracyjna, „Wiadomości” 1959, nr 34.

Wittlin J., Pochwała kobiety piszącej, „Wiadomości” 1961, nr 25.

Wittlin J., Sono felice..., „Wiadomości” 1975, nr 73.

Wojtasik K., Dama polskiej literatury, „Tydzień Polski” 1975, nr 215.

Wyka M., Zapomniana sztuka fabuły, „Pismo” 1983, nr 1/2.

Zaremba P., Słońce dziesięciu linii, „Orzeł Biały - Syrena” 1963, nr 26.

Zbyszewski K., Nastrój nie bije ze „Szklanej kuli”, „Dziennik Polski i Dziennik Żołnierza" 1964, nr 301.

Zieniewicz A., Odmiany paktów autobiograficznych $w$ literaturze XX wieku [w:] Dwudziestowieczność, M. Dąbrowski, T. Wójcik (red.), Warszawa 2004. 